\title{
¿La pintura novohispana como una koinépictórica americana? Avances de una investigación en ciernes
}

Creo que debe establecerse una distinción muy importante entre aquello de lo que estamos seguros y lo que podemos creer o aquello sobre lo que podemos establecer una hipótesis... Si se sabe que se puede reconstruir lo que era la situación, se puede reconstruir también cómo una persona razonable ha reaccionado ante la situación.

Ernst Gombrich, Lo que nos cuentan las imágenes. Charlas sobre $\mathrm{e}$ artey la ciencia

\section{Estado de la cuestión}

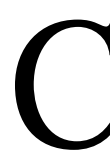

aracterizar la pintura novohispana no es una tarea sencilla; podemos distinguir una pintura peninsular de una americana, pero no definir esta última. Existen tal cantidad de elementos discordantes que se vuelven inexplicables en conjunto debido a la diversidad de orígenes, tradiciones, escuelas, etc., que sólo han llevado a conclusiones opuestas y, a

I. Una versión preliminar, sintética y sin algunas novedades que últimamente he trabajado, fue presentada en el "Encuentro Internacional sobre Barroco Andino" en Santa Cruz de la Sierra, Bolivia, en diciembre de 2002. 
veces, contradictorias dentro de la historia del arte. Parecería que tenemos todas las piezas y, sin embargo, no podemos armar el rompecabezas.

El presente artículo intenta explicar, estableciendo un paralelismo con la lingüística, particularmente en lo relacionado con la descripción del español americano y su formación, cómo se conformó la mentalidad del pintor en los reinos mediante un proceso denominado koiné o nivelación, consistente en dejar de lado las particularidades de cada uno en favor de lo que todos compartían, creando un nuevo lenguaje y un sentido de pertenencia a un grupo, acomodándose así a una nueva realidad.

Uno de los problemas básicos que se presenta al explicar la pintura novohispana, y quizá toda la pintura americana del periodo virreinal, es precisar cuál es su deuda con la pintura española y cuál con la herencia indígena. Varias preguntas sobre la personalidad artística de esta pintura ya fueron hechas en el pasado, de las cuales, algunas quizá hoy no se consideren pertinentes y, para otros, ya están contestadas. Así, preguntas como: ¿La pintura novohispana pertenece a la escuela española como una rama independiente 0 es parte de esta escuela sin más?, pero entonces ¿por qué casi sin lugar a dudas podemos distinguir una pintura novohispana de una española o de una peruana, por ejemplo? ¿Q ué tanto podemos hablar sobre la influencia indígena en la pintura novohispana? ¿El término "mestizo" es adecuado para calificar la producción pictórica americana como lo ha sido para la arquitectura? ¿Por qué un pintor como Sebastián López de Arteaga cambia su estilo personal al poco tiempo de llegar a la N ueva España? ¿Por qué un grupo de pintores novohispanos del siglo xviı pintan en forma tan similar que, cuando se nos pregunta por la autoría de una pintura, podemos contestar: "quizá sea C abrera o puede que sea Vallejo o M orlete en algún momento de su producción 0 quizá también Alzíbar"? ¿Por qué en algunos casos no podemos ir más allá del equívoco "estilo de una época" para avanzar sobre el "estilo personal" de los autores? ¿Por qué apenas distinguimos a estos pintores del xviII novohispano entre ellos? La respuesta a estas últimas preguntas podría ser tan obvia como que no los hemos estudiado lo suficiente. Pero me temo que, a pesar del conocimiento metódico que podamos tener en el futuro de estos pintores, queda intacta nuestra pregunta: ¿Por qué esa unidad exagerada? ¿Por qué

2. Rogelio Ruiz Gomar, "La colección de pintura colonial del Ateneo Fuentes, en la ciudad de Saltillo, Coahuila", Anales del Instituto de Investigaciones Estéticas, núm. 6o, Universidad Nacional Autónoma de M éxico, Instituto de Investigaciones Estéticas, I989, p. 88. 
el historiador de la pintura colonial José Bernardo Couto, al definir la "escuela novohispana de pintura" a finales del siglo xix, tenía en mente la pintura del siglo xvin y no la del siglo xvir, que incluso él consideraba mejor? La respuesta sería que en la del xviı encontraba de manera más pal pable semejanzas que por repetidas se convertían en "Io característico" y que esto él lo consideraba como una escuela. Estas preguntas, y otra docena más que se podrían agregar, son tan viejas como nuestro quehacer en M éxico; ahí está el mismo Couto, que en i86i ya se las hacía con respecto a la filiación europea del arte colonial , 4 o Francisco D iez Barroso, quien en i92 I las contestaba con tan acendrado hispanismo que le valió ser olvidado en la historia del arte mexicano.5

¿Vale la pena tratar de responder preguntas tan viejas? ¿Tiene sentido para lo que hacemos hoy tratar de responder éstas y otras preguntas? Pero también, ¿fueron en otras épocas realmente respondidas? ¿Podemos, a través de las respuestas a estas interrogantes, discernir qué es lo que a estos pintores los une estilísticamente para sólo de esta forma llegar a las diferencias y caracterización de la pintura novohispana o peruana frente a la española?

3. José Bernardo C outo, D iálogo sobre la historia de la pintura en M éxico, estudio introductorio de Juana Gutiérrez $\mathrm{H}$ aces, notas de Rogelio Ruiz Gomar, M éxico, Consejo N acional para la Cultura y las Artes (Serie Cien de M éxico), 1995.

4. Couto, por boca de José Joaquín Pesado, uno de los interlocutores en el "D iálogo", decía: "M as sea lo que fuere de las obras de los indios, ellas nada tienen que hacer con la pintura que hoy usamos, la cual es toda europea, y vino después de la Conquista. Si los mexicanos pintaban (y en efecto pintaron mucho), ése es un hecho suelto que precedió al origen del arte entre nosotros; pero que no se enlaza con su historia posterior", op. cit., p. 7I. A pesar de esta contundente declaración, el D iálogo sobre la historia de la pintura en M éxico está enteramente escrito con el objeto de reconocer una "escuela nacional" de pintura.

5. Francisco Diez Barroso, El arte en la Nueva España, M éxico, edición del autor, 1921. "En efecto, cuando ha existido mezcla de civilizaciones, la mezcla de las tendencias artísticas también ha aparecido, produciendo tantas manifestaciones híbridas como nos revela la historia del arte y que caracterizan a los periodos de transición [... ] Algo similar hubiera acontecido en la N ueva España si hubiera habido mezcla de civilizaciones, de religiones, de costumbres [... ] Pues bien, nada semejante aconteció en Nueva España [... ] Por ello puede decirse del modo más categórico que no hubo la menor mezcla de tendencias artísticas, sino substitución completa y absoluta [... ] Así, pues, el carácter fundamental del arte en $\mathrm{N}$ ueva España fue su españolismo, esencial y exclusivo, al grado de que aquél debe considerarse y estudiarse como una rama, genuina y fecunda, del maravilloso arte español", pp. 25-26. 
DOI: http://dx.doi.org/10.22201/iie.18703062e.2002.80.2107

50

JUANA GUTIÉRREZ HACES

La ciencia explica, la historia constata

Es evidente que los conceptos de estilo y escuela están al centro de estas preocupaciones, si es que queremos explicar nuestro objeto de estudio. Unido a estos conceptos, tan discutibles para algunos, no se puede dejar fuera el concepto de tradición, comúnmente confundido con el de escuela al nombrar, por ejemplo, "la tradición flamenca", o "la española", etc. La tradición se entiende como una conciencia siempre presente de "lo heredado" y como una respuesta, consecuente con esta idea, de asumir una actitud, en algunas ocasiones, consciente de mantener vivas las tradiciones y los valores de lo que se considera propio. Como lo diría mejor E.H. Gombrich: crear una "cadena viva de tradición" con el fin, bastante alejado de una actitud conservadora, de construir nuevas formas por medio de esas tradiciones locales y de conservar las "convenciones" transmitidas por medio de los talleres que permiten al artista tener una base para de ahí partir hacia la creación. Es lo que el mismo Gombrich, haciendo uso de un concepto de ingeniería aplicado al lenguaje, Ilamaba "retroalimentación" o "círculo virtuoso". Lo que lle varía, por lo tanto, a considerar estas tradiciones como fuente de una identidad formal. Sería, al fin y al cabo, "la persistencia de las tradiciones tras la fachada cambiante de los estilos de cada periodo". 6 Parte de esta continuidad se puede observar en la pintura novohispana a través de las "citas" que hacen los pintores de sus antecesores locales.7 Todo dentro de una actitud, que le hubiera gustado observar a Warburg, de una sociedad dispuesta a preservar

6. Estos temas han sido en múltiples ocasiones tratados por Ernst H. Gombrich. Citaremos sólo algunos de los artículos donde los trata: "La necesidad de la tradición. Interpretación poética de I. A. Richards (I893-I979)", en Tributos. Versión cultural de nuestras tradiciones, M éxico, Fondo de Cultura Económica, I99I, pp. I80-204; "Los viejos maestros y otros dioses familiares", publicado en The Independent, 6 de enero de 1990 , con motivo del $40^{\circ}$ aniversario de la primera edición inglesa de La historia del arte, en Gombrich esencial. Textos escogidos sobre arte y cultura, edición de Richard Woodfield, M adrid, D ebate, 1997, p. 38; y, desde luego, Arte e ilusión, Barcelona, Gustavo Gili, 1979, y M editaciones sobre un caballo de juguete, Barcelona, Seix Barral, 1968.

7. Rogelio Ruiz Gomar, "La tradición pictórica en el taller novohispano de los Juárez", en Primer seminario sobre pintura virreinal, Lima/M éxico, O rganización de Estados I beroamericanos para la Educación, la Ciencia y la Cultura/Fomento Cultural Banamex/Instituto de Investigaciones Estéticas (en prensa), y Juana Gutiérrez $\mathrm{H}$ aces, "The Painter Cristóbal de ViIlalpando: H is Life and Legacy", en N ew World Art Symposium, D enver, D enver Art M useum (en prensa). 
la "vida futura de las formas", aunque aquí la distancia espacial y temporal, de lo que él estudiaba, fuera absolutamente diversa. ${ }^{8} \mathrm{Así}$, las preguntas sobre el estilo, el grupo que lo practica en un lugar y tiempo específicos, y los deseos de continuidad de ciertos rasgos en "la historia de la fabricación de imágenes" son aún vigentes.

Sin embargo, como dice E.H . Gombrich, habría que interesarse no sólo en la historia del arte tal como se enseña, sino en algo diferente. Esa diferencia residiría en el interés en las explicaciones. Gombrich dice: "M i principal interés siempre ha estado en las explicaciones de tipo más general, lo que significa cierto parentesco con la ciencia. La ciencia trata de explicar. En historia, constatamos; pero en ciencia tratamos de explicar hechos aislados comparándolos con una regularidad general". Y, centrándose en el tema que nos interesa, añade:

Estudié el tema en favor de la explicación - es decir, la explicación del fenómeno estilo- porque el fenómeno del estilo tal como se ha visto tradicionalmente no me satisfacía. El estilo se convirtió en una de mis preocupaciones, uno de mis problemas, porque la idea de que estilo es simplemente la expresión de una época me parecía que no sólo decía muy poco, sino que era bastante vacua en todos los aspectos. Q uería saber qué estaba ocurriendo en realidad cuando al guien dibuja un árbol de una manera determinada, en una determinada tradición y en un determinado estilo.

Y más adelante: "Además, se puede uno preguntar: ¿cómo cambia la tradición? ¿Cuál es su influencia? [... ] Todo esto debe interesar a cualquiera que contemple el desarrollo en su conjunto y haga la pregunta incómoda: 'Pero ¿por qué? ¿Por qué? ¿Q ué ocurrió en realidad en aquel momento?'" Gombrich concluye: "No digo que pueda responderse totalmente a esta pregunta alguna vez, pero siempre se puede especular, y esto no siempre es inútil."

8. Lo interesante es encontrar que esta actitud sobre la tradición artística no sólo se observaba pictóricamente en la N ueva España, sino también en la literatura artística contemporánea al leer algunos párrafos sobre los pintores en la obra de Sigüenza y G óngora, Triunfo parténico, primero, y después, por ejemplo, en la transcripción de un texto perdido del pintor José de Ibarra, por M iguel Cabrera, en su M aravilla americana, por citar sólo dos ejemplos.

9. En "Un apunte autobiográfico", transcrito a partir de la grabación de una charla informal ofrecida en la Rutgers University, N ueva Jersey, en marzo de 1987. Publicado en Gombrich esencial..., pp. 33-35. En dicho "apunte" reconoce su deuda con Karl Popper. 
D e similar forma, el lingüista Amado Alonso dice: "La ciencia es tarea que se va cumpliendo sin detenerse nunca, y como puede ser un sabio tan ilustre por los problemas que se plantea y resuel ve como por los que obliga a sus colegas y sucesores a replantear y resolver." "г

M otivada y siguiendo tales aseveraciones creo que en la historia de la pintura virreinal americana hay que empezar de nuevo a reformular preguntas, algunas que incluso ya se habían hecho, e intentar dar explicaciones más allá de los determinismos geográficos o del romántico "espíritu de la época".

Ante tan perentoria llamada de atención por parte de Gombrich (y de otros autores) y considerando lo difícil que puede ser definir lo que es "científico" en nuestra disciplina, con el peligro de hundirme en el campo vecino de la lingüística, intento construir una explicación de lo sucedido en la pintura novohispana.

\section{Pintura española de América o en América}

D entro de la lingüística existe un campo específico dedicado al estudio de la lengua española en América y es a este campo al que me remito con el objeto de obtener instrumentos para intentar dar una explicación del fenómeno llamado "pintura novohispana".

Al igual que los lingüistas, la primera pregunta que tendríamos que hacernos es si la pintura novohispana es pintura española en América o pintura española de América. ${ }^{\text {II }}$ Pregunta básica que los lingüistas se hacen con respecto a la lengua española hablada en el continente americano.

Ya desde el siglo xix, como hemos visto, en el campo del arte se habían tomado posiciones a este respecto, y aunque no es lugar para abundar sobre ello, anotemos de pasada que tanto José Bernardo Couto (I86I) como el doctor Lucio (1863-1864), ${ }^{12}$ al igual que Ignacio M anuel Altamirano

Io. Prólogo de Amado Alonso a la edición española de la obra de Ferdinand de Saussure, Curso delingüística general, ıoa. ed., Buenos Aires, Losada, p. 7 [ra. ed., 1945].

iı. José G. M oreno de Alba, El español en América, za. ed. corregida y aumentada, M éxico, Fondo de Cultura Económica (Lengua y Estudios Literarios), 200I, p. 7.

I2. Rafael Lucio, Reseña histórica de la pintura mexicana en los siglos XVII y XVIII, M éxico, O ficina Tipográfica de la Secretaría de Fomento, i889. Lucio dice: "N o por eso se crea que la marcha de la pintura mexicana se semeja a la de otros países, que sus progresos fueron resultado de esfuerzos individuales que mejoraron y adelantaron el arte hasta llevarlo a su perfección 
(I883), ${ }^{13}$ dieron su veredicto, cada uno desde posturas políticas diferentes (los dos primeros del bando conservador, el segundo del liberal), y concluyeron que lo que se hacía en M éxico era pintura española. Sin embargo, ellos mismos se daban cuenta de que la pintura hecha en estas tierras era diferente a la escuela española, de la misma forma como nosotros lo hacemos. El siglo xix solucionó todo hablando de un clima, una tierra más benéfica y una condición racial más dulce, muy acorde con los determinismos decimonónicos en boga. Fue sólo hasta i893 que M anuel Revilla considera que el arte virreinal tiene características tales como para considerarlo original y diferente; así, dice: "M as no bien entrado el siguiente siglo, míranse rodeados de discípulos nacidos muchos en la Colonia, a quienes transmiten su saber, y debido a las multiplicadas demandas de obras que unos y otros reciben, la producción aumenta y aparece una nueva manifestación artística que, aunque derivada de los españoles, puede ser considerada indígena." A esta afirmación, que se debe entender como la primera declaración de reconocimiento de un arte posterior a la conquista diferente del español y con origen en estas tierras, Revilla también añade, por primera vez, dentro de un libro dedicado al arte, un apartado dedicado únicamente al arte prehispánico y no sólo reconoce que parte del carácter del arte mexicano se debe a la presencia del arte indígena, esta vez entendido como el de los indios y no como originario de estas tierras, pero además considera que hay continuidad entre un periodo y otro, aunque para la reedición de su libro en 1923 acaba por hacer un reconocimiento mayor a la deuda con España. ${ }^{14}$

relativa, para entrar después en una época de decadencia. En M éxico no sucedió así: la pintura fue importada de España en su mejor época, ya formada, aun en sus procedimientos materiales de ejecución, y desde principios del siglo xvir hasta fines del xvin, ha seguido una marcha decadente con muy ligeras oscilaciones", p. 5. Para C outo, op. cit., nota 3. La primera edición de Couto fue en 1872 como edición póstuma.

I3. I gnacio M anuel Altamirano, "Revista artística y monumental", en el Primer almanaque histórico, artístico y monumental de la República mexicana, publicado por Manuel Caballero, N ueva York, I883-1884, recogido en I gnacio M anuel Altamirano, 0 bras completas, escritos de literatura y arte, M éxico, Consejo Nacional para la Cultura y las Artes, I989, t. 3, pp. I79-20I. Altamirano desprecia profundamente la pintura virreinal, a la cual califica por primera vez de colonial, además de que su acendrada religiosidad le disgusta, lo que le hace concluir que esta escuela colonial no tiene nada de nacional.

I4. M anuel Revilla, El arte en M éxico en la época antigua y durante el gobierno virreinal, México, Secretaría de Fomento, I893. Revilla dice: "Y es de ver a este propósito cómo en M éxico desde remota antigüedad se rinde culto a lo bello, apareciendo las manifestaciones de tal culto 


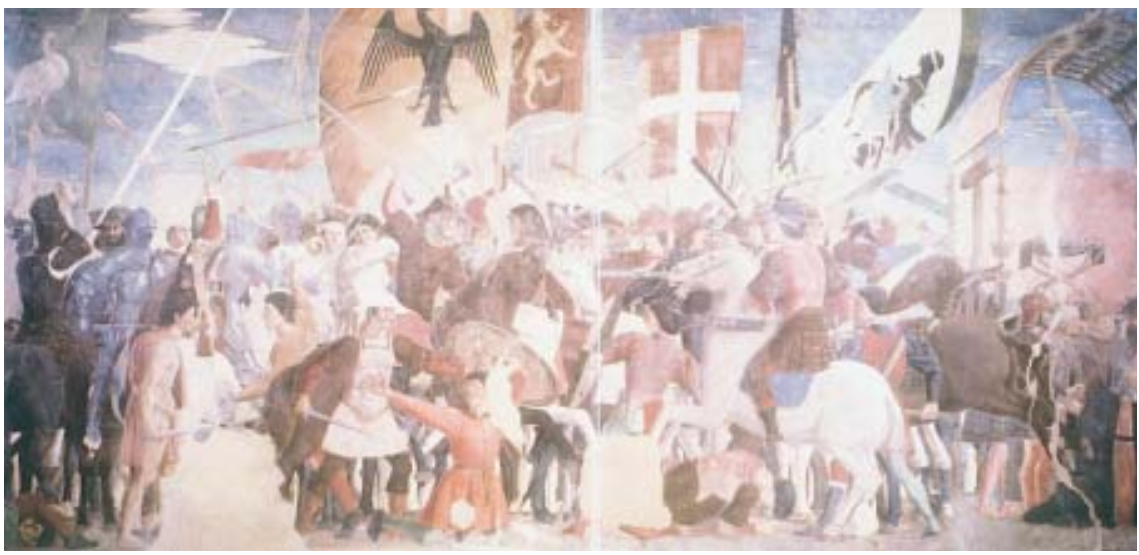

I. Piero de la Francesca, Batalla y muerte de Cosroes, iglesia de San Francisco, Arezzo.

Ante la necesidad de caracterizar nuestra pintura virreinal, la pregunta sobre la deuda con la pintura española sigue vigente. $Y$ para responder a tal pregunta tendremos primero que deshacernos de nacionalismos y de antihispanismos y aun cuando la respuesta no sea tan "políticamente correcta", desde el punto de vista de las actuales políticas étnicas, sólo será tratando de entender un fenómeno como obtendremos respuestas. Sin embargo, no es el momento de concluir con una respuesta que fácilmente se convertiría en una lectura de principios, sino de observar la realidad pictórica en vistas a una explicación futura de lo que es la pintura en la N ueva España.

Lo que parecería claro, a simple vista, independientemente de lo que se concluya, y afirmando que la pintura que se hizo en esta región es pintura española de América 0 en América, ${ }^{15}$ es que ésta tuvo a partir de determinado

dotadas de patente de originalidad; pues no obstante las analogías que puedan existir entre las construcciones de los indios, por ejemplo, y las de al gunos pueblos del 0 riente, 0 entre la pintura cultivada después de hecha la C onquista y la propiamente española, ello es que las primeras ofrecen rasgos típicos inconfundibles, que la pintura al domiciliarse entre nosotros adquirió caracteres y variantes que en vano se buscarán en autores españoles. Por tanto, sería lo mismo que truncar la historia de las nobles artes el desdeñar y omitir el estudio de los palacios de M itla, de las pinturas de los Juárez o de las estatuas de Tolsá", p. 8. La segunda edición corregida y aumentada es El arte en M éxico, M éxico, Porrúa, I923.

I5. El empleo del de o del en no deja de tener sus consecuencias: el mismo M oreno de Alba, op. cit., citando a M ontes, a Rivarola y a sí mismo, explica: "Sobre el empleo de esta preposi- 


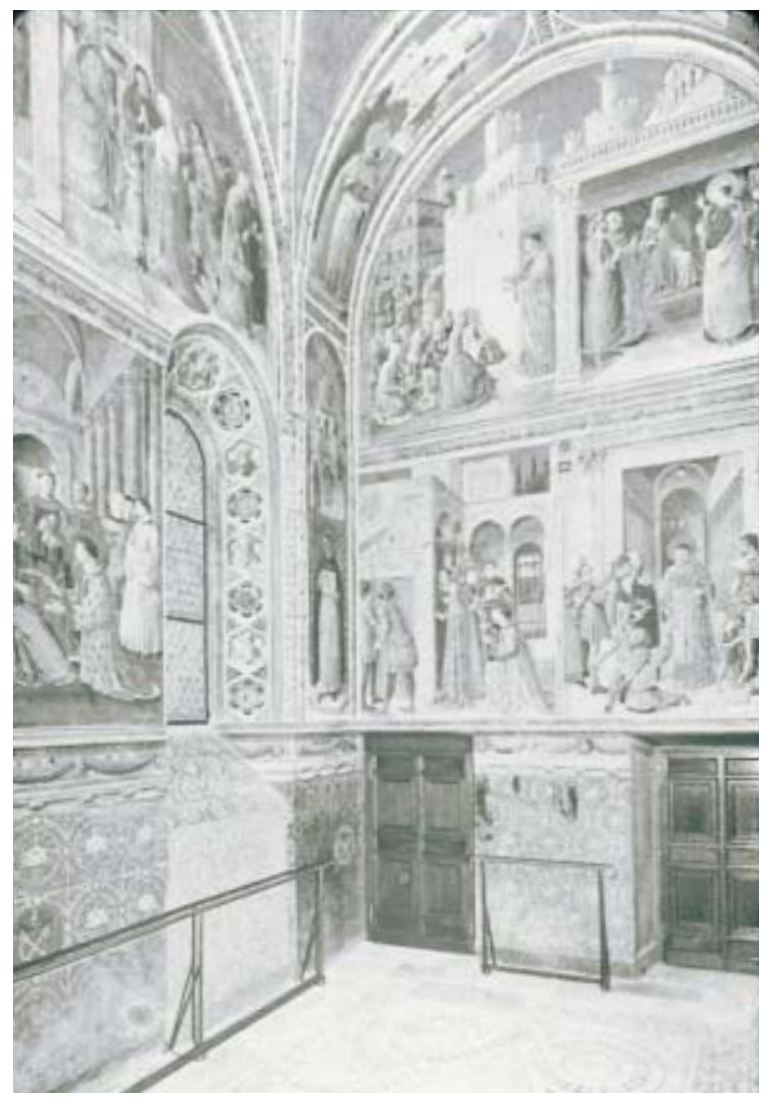

2. Fray Angélico, capilla de Nicolás $V$, Vaticano. Foto: cortesía de los M onumenti, M usei e Gallerie Pontificie.

ción en en lugar de de escribió M ontes (1989: 644): 'el uso de en en este caso en vez de de parece envolver una concepción del español americano como algo ajeno, importado y no creado (o cocreado) por los americanos en su uso diario a lo largo de cinco siglos'. Ciertamente parece convincente esa opinión, pues no puede uno sino estar de acuerdo en que el español de América, como español de M éxico o español de España, son entidades históricas identificables, planteamiento sustentado 'en las colectividades humanas que las emplean, las desarrollan, reflexionan sobre ellas, las integran a su conciencia cultural, las convierten en señas de identidad' (Rivarola, I99oa: 24). Sigo creyendo, empero, que, lingüísticamente hablando, no hay una entidad americana que pueda oponerse, como un todo, a otra totalidad (el español europeo). No falta quien, como yo, prefiere emplear la preposición en mejor que de: 'Lo que se suele llamar 'español de América' es un conjunto de dialectos, un suprasistema o diasistema, es 


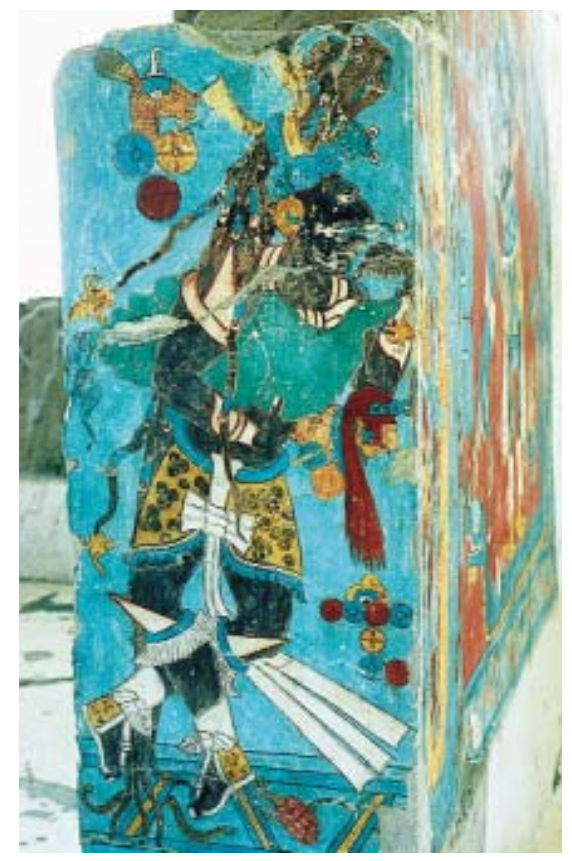

3. Cacaxtla, Tlaxcala. Jamba Sur, pórtico. Conaculta-INAH-M éx. Reproducción autorizada por el Instituto Nacional de Antropología e H istoria. Foto: Amada M artínez, Archivo Fotográfico IIE-UNAM.

momento un desarrollo autónomo de España. ${ }^{16}$ También debemos agregar que los estudios lingüísticos siguen su marcha en cuanto a transformaciones se trata, al seguir el español americano evolucionando hasta nuestros días, mientras que un historiador del arte puede considerar como concluida la etapa en la que el arte novohispano utilizaba el lenguaje pictórico español.

decir, una abstracción irrealizable en sí misma [... ] Según ese planteamiento, en lugar de hablar de español de América, sugiriendo la presencia de una modalidad, sería más apropiado referirse al español en América, con lo cual se insinúa al menos la idea de varias modalidades lingüísticas americanas. (M oreno de Alba, 1992: pp. 63 y ss.)'", pp. 7-8.

I6. Resulta importante observar que Ferdinand de Saussure consideraba que: "todo cuanto se refiere a la extensión geográfica de las lenguas y a su fraccionamiento dialectal cae en la lingüística externa. Sin duda, éste es el punto donde la distinción entre ella y la lingüística interna parece paradójica: hasta tal extremo está el fenómeno geográfico estrechamente asociado con la existencia de toda lengua; y, sin embargo, en realidad, la geografía no toca el organismo interno del idioma", op. cit., p. 68. M oreno de Alba dice al respecto: "Sin dejar de reconocer la necesidad de emprender una historia del español de América menos eurocentrista - como lo 
4. Cacaxtla, T laxcala. Edificio B. M ural de la Batalla, talud oriente. Personaje olmeca-xicalanca. Conaculta-ınaH-M éx. Reproducción autorizada por el Instituto Nacional de Antropología e H istoria. Foto: G erardo Vázquez y Eumelia H ernández, Archivo Fotográfico IIE-UNAM.

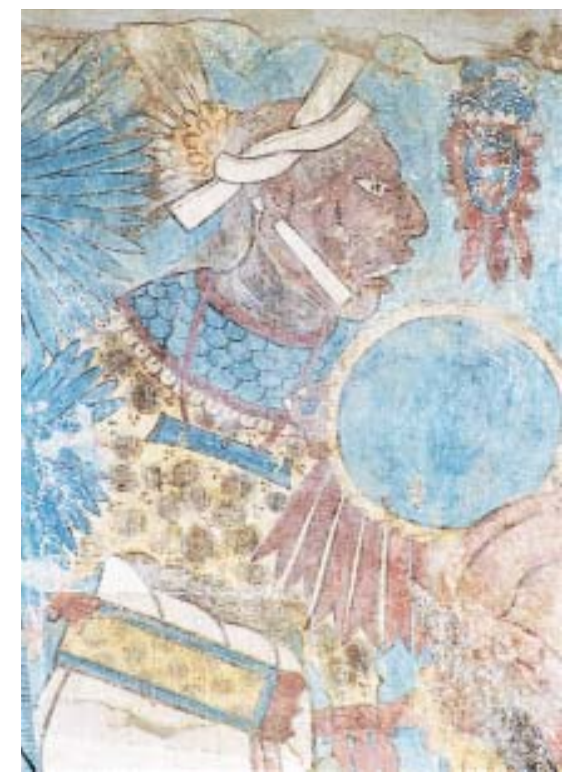

Q uizá la explicación que, por obvia, tenemos todos en mente respecto a estas diferencias pudiera ser la inclusión de la mano indígena y, por qué no, también de una tradición que aún hoy no está perdida. Sin embargo, considerar que lo distintivo en la pintura americana virreinal, y en particular de la novohispana, es su nexo con los indígenas o con el indigenismo resulta muy discutible.

Aun cuando puede considerarse forzado aplicar a un lenguaje no verbal, como la pintura, procesos nacidos del lenguaje oral, existen términos apropiados para entender procesos similares. Así, dentro del estudio de las lenguas existe el término sustrato, llamado de esa manera "por su analogía con

sugiere Roth (1986: 266): en los estudios de historia del español americano 'el criterio decisivo lo constituye el criterio diferencial, esto es, la diferencia frente a la norma europea'- no pueden evitarse, en un libro como éste, creo yo, las referencias casi constantes a las semejanzas y, sobre todo, a las diferencias observables entre el español en América y el español en España. Resulta innegable, a mi ver, la necesidad de explicar cómo y por qué el español, en América, sin perder su unidad esencial con el europeo, va adquiriendo, en los diversos niveles (fonológico, fonético, gramatical y léxico), su propia fisonomía que debe contrastarse necesariamente con la del español peninsular", op. cit., p. io. 
DOI: http://dx.doi.org/10.22201/iie.18703062e.2002.80.2107

58

JUANA GUTIÉRREZ HACES

las capas geológicas". Se da el nombre de sustrato "a la lengua que, a consecuencia de una invasión de cualquier tipo, queda sumergida y sustituida por otra. La lengua invadida no desaparece sin dejar teñida a la invasora de al gunos rasgos". ${ }^{17}$ Las teorías sustráticas de Ascoli aplicadas a la expansión del latín estuvieron en boga a finales del siglo xix y pronto los estudios sobre el español americano las tomaron, ya que éste, el español, es un típico caso de lengua trasplantada y superpuesta a otras habladas previamente por una población sometida. Incluso, para muchos, como H enríquez U reña, ${ }^{{ }^{8}}$ el factor de diferenciación de las múltiples formas de hablar el español en América se podría entender a través de las diferentes alianzas del español con los distintos y variados sustratos indígenas a todo lo largo del continente. Posición, ésta, nacida dentro de un clima nacionalista en M éxico, pero no aislada, ya que también existían los estudios de Rodolfo Lenz, anteriores en fecha (1893), quien defendía la tesis de que el español hablado por el vulgo en Chile "es principalmente español con sonidos araucanos" ${ }^{19}$ Esta posición fue amplia-

17. Fernando Lázaro C arreter, D iccionario de términos filológicos, M adrid, Gredos (Biblioteca Románica H ispánica), 1971, p. 386.

I8. Pedro Henríquez U reña, O bservaciones sobre el español de América, Revista de Filología Española, núm. 7, 1921, pp. 357-390. Citado en Fontanella, "La conformación de las distintas variedades del español americano", en El español de América, M adrid, M apfre, pp. 25-54.

I9. Amado Alonso, "Examen de la teoría indigenista de Rodolfo Lenz", en Estudios lingüísticos. Temas hispanoamericanos, M adrid, Gredos (Biblioteca Románico H ispánica II, Estudios y Ensayos I2), 1976, p. 268 [ra. ed. 1953]. Amado Alonso, a pesar del gran respeto que profesaba por Lenz, el cual hace patente en una nota de reconocimiento por su valía académica, va refutando una por una sus tesis probando que este autor había hecho sus estudios sobre la lengua de su época sin considerar que, de la misma forma que había evolucionado el español a partir del siglo xvi, lo había hecho el araucano, y que todos los elementos que él había considerado araucanos preexistían en la lengua española. Por desgracia, uno de los problemas de quienes hicieron este tipo de estudios es que no conocían a profundidad la evolución del español mismo, ya que para ese momento se sabía poco al respecto. Sin embargo, tratando de eliminar dudas respecto a su posición, Amado Alonso agregó: "El tema del sustrato en el español de América tiene que ser uno de los más importantes objetos de estudio. D e ningún modo me he propuesto hacer para el chileno una averiguación de limpieza de sangre, ni defender al español de América de la sospecha de mestizaje. En la investigación histórica, los hechos o interpretaciones firmemente averiguadas nos deben dar la misma satisfacción - en el terreno científico- tanto si halagan como si hieren a otras actitudes vitales e interesadas", p. 319. Esta última aseveración la hace en función del reconocimiento al esfuerzo académico y científico de Lenz. Alonso enumera algunas exigencias metodológicas que deberán guiar los estudios a futuro, y entre ellas, la última, afirma: “Es obvio que se requiere un conocimiento seguro de las tenden- 
DOI: http://dx.doi.org/10.22201/iie.18703062e.2002.80.2107

¿LA PINTURA NOVOHISPANA COMO UNA KOINÉ ?

mente rebatida por Amado Alonso y una larga lista de lingüistas al considerarla absolutamente equívoca por difícil que nos parezca a los que no somos lingüistas. ${ }^{20}$

\section{Aportaciones lexicalesindígenas}

En épocas recientes, la discusión sobre el verdadero peso de la influencia de las lenguas indígenas se ha puesto de nuevo en discusión, concluyendo que su lugar dentro del español sólo es lexical, es decir, en el vocabulario aislado, existiendo pocas transformaciones fonológicas y morfosintácticas ${ }^{21}$ que nos

cias dialectales y vulgares propiamente hispánicas, y una información circunstanciada de la geografía lingüística de cada hecho dialectal; como principio (y en realidad así se ha creído proceder siempre en los estudios sustratistas de todas las lenguas), sólo se recurre a explicar un hecho en la historia de una lengua por la intervención de otra heterogénea, cuando no se puede aclarar dentro del sistema propio. Este principio tiene que seguir valiendo en nuestro caso; y además, un privilegio tenemos sobre los que estudian sustratos prehistóricos: que hay la posibilidad de sorprender actuando factores concurrentes, un germen hispánico desarrollado gracias a disposiciones sustratistas favorables, o sea, el hecho complejo y delicado en que el sustrato no es fermento pero sí fomento del cambio".

Este principio metodológico deberá ser absolutamente tomado en cuenta en la investigación artística si queremos llegar a resultados, en cuanto sea posible, científicos. Amado Alonso más adelante añade, en un admirable ejercicio de honestidad académica y científica: "sobre los temas propuestos por Lenz hemos llegado a un conocimiento de signo negativo, pero de carácter científico. Ahora bien, en el conocer, lo que importa es la cualidad científica del conocimiento, aparte si nos conduce a un sí o a un no", p. 32I.

20. Citado en Fontanella, op. cit., pp. 25-54.

2I. Elena Lozanova, "N otas sobre la utilidad del léxico indígena en el español contemporáneo", en Estructuras en contexto. Estudios de variación lingüística, edición de Pedro M artín Butragueño, M éxico, El C olegio de M éxico, 200o, pp. 6I-79. La autora asevera: "Aunque existen numerosos estudios que afirman la influencia de las lenguas indígenas en el ámbito fonéticofonológico o morfo-sintáctico del español, es el nivel léxico, el más superficial, el que propicia en mayor grado una penetración del sustrato indígena tanto en el léxico común como el español regional americano. Las lenguas que han prestado mayor cantidad de indigenismos son las variedades lingüísticas antillanas, el náhuatl y el quechua, llamadas también lenguas generales... [ [llamadas así por ser las que se enseñaron a todos por igual para ser usadas para evangelizar]. El análisis de textos cronísticos y obras lexicográficas señala sus limitaciones en cuanto al número de indigenismos anotados y al uso real de este tipo de vocablos. Los diccionarios de americanismos no contemplan, generalmente, factores diatópicos y diastráticos, sino que pro- 
60

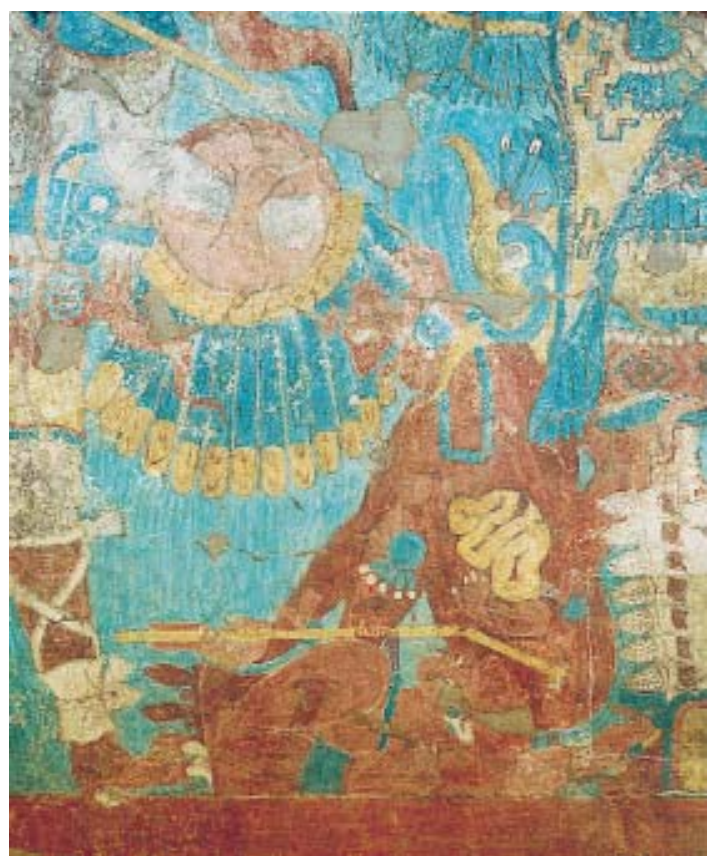

5. Cacaxtla, T laxcala. Edificio B. Mural de la Batalla, talud oriente. Personaje con los intestinos de fuera. ConacultaINAH-M éx. Reproducción autorizada por el Instituto N acional de Antropología e H istoria. Foto: Eumelia H ernández, Archivo Fotográfico IIE-UNAM.

hicieran creer que existe un español mestizo. Incluso algunos, como Bertel $M$ almberg, concluyen que: "no deben considerarse como fenómenos de sustrato aquellos en que la influencia se reduce a meros préstamos lexicales, sino que se debe restringir la denominación a los casos en que haya interferencias fonológicas o morfosintácticas". ${ }^{22}$ D ebemos observar, para los legos en estos

curan registrar alfabéticamente todos los variados vocablos indígenas que podían documentar de una u otra manera. Sin embargo es necesario considerar parámetros sociolingüísticos, la difusión geográfica, la productividad y la riqueza semántica de los préstamos indígenas", p. 62.

22. Aún hoy la discusión está viva y se toma en cuenta para discutir las posiciones lexicales, la glotalización yucateca, los gentilicios mexicanos terminados en "eco" y el caso entero de Paraguay no sólo por su aislamiento, sino por un bilingüismo vivo hasta nuestros días. Citado 


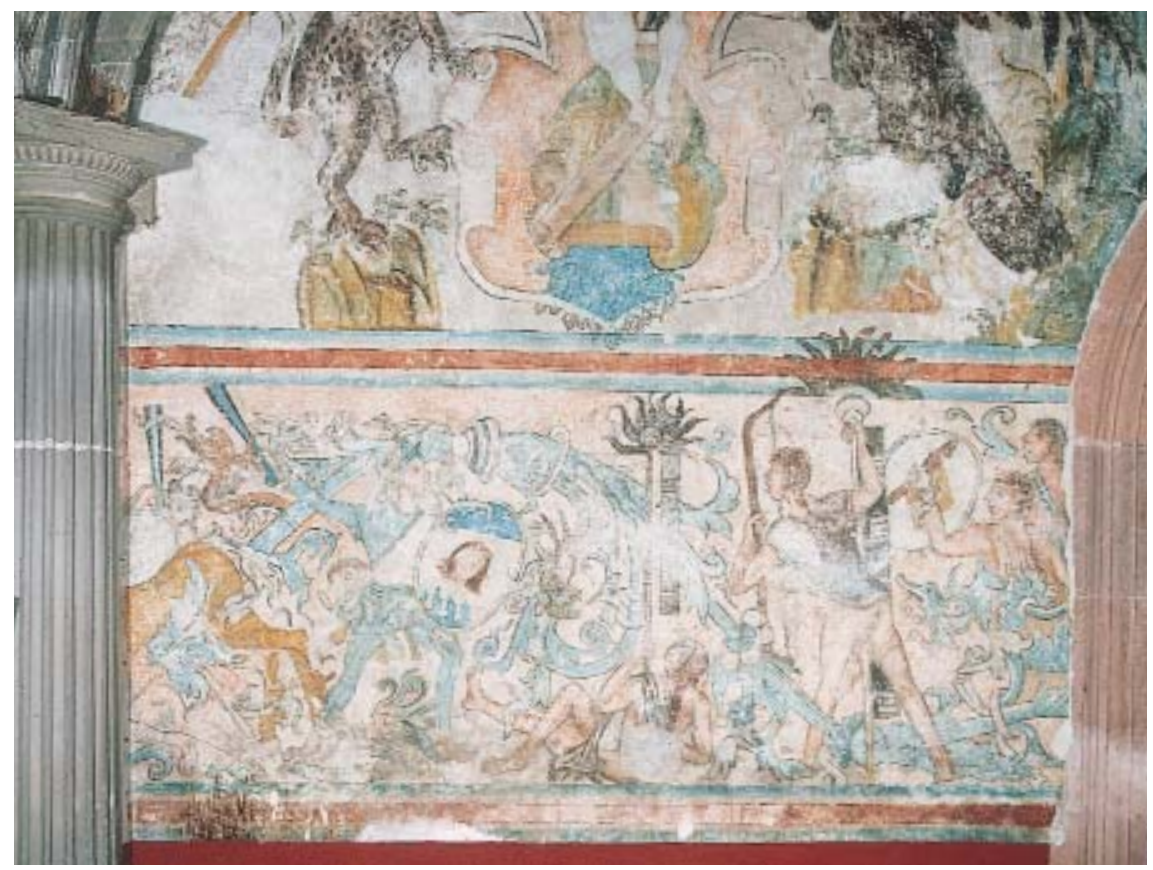

6. Ixmiquilpan, Hidalgo. M urales de la batalla, interior de la iglesia. Conaculta-ınaH-M éx. Reproducción autorizada por el Instituto $\mathrm{N}$ acional de Antropología e H istoria. Foto: Pedro Ángeles, Archivo Fotográfico IIE-Unam.

estudios, que nuestros colegas lingüistas analizan tantos o más documentos de las épocas aludidas que los historiadores para llegar a estas conclusiones. Así, Lope Blanch, para subrayar esta escasa influencia indígena en el español, afirma que para el caso de M éxico el papel del léxico de origen indígena es muy secundario, ya que su frecuencia en la vasta lengua española apenas Ilega al 0.7 por mil. ${ }^{23}$

por M oreno de Alba, op. cit., p. inI, y Fontanella, op. cit., pp. 29-30. “D entro de su concepción estructuralista, $M$ almberg considera que en el estudio de la evolución lingüística debe optarse siempre por las explicaciones generales frente a las particulares; que se han de preferir las explicaciones internas frente a las externas; que los cambios que significan una simplificación en el sistema son explicables preferentemente por una reducción interna más que por el influjo de sustrato; y que antes de adoptar una interpretación sustratista debe tenerse en cuenta si la situación sociocultural la justifica", Fontanella, op. cit., pp. 30-3I.

23. Citado por Fontanella, op. cit., p. 29. Resulta interesante que M anuel Toussaint, al escri- 


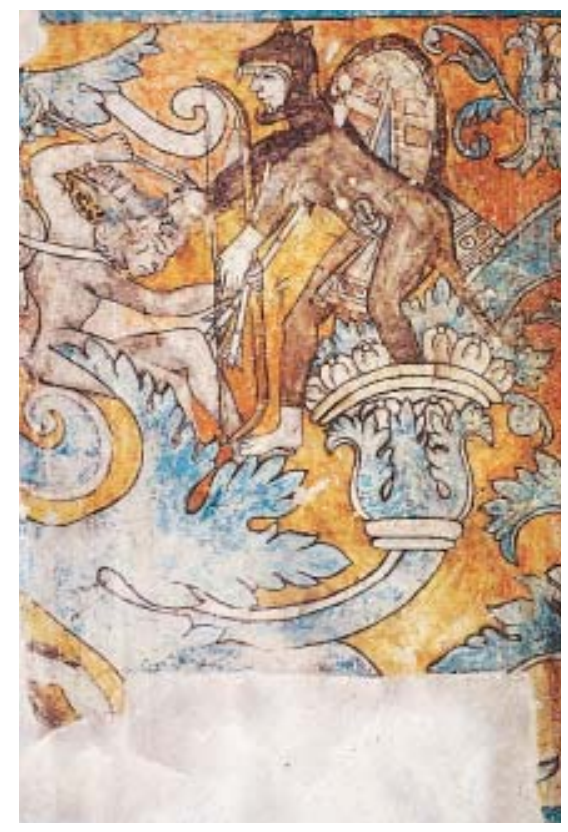

7. Ixmiquilpan, Hidalgo. Murales del muro norte, interior de la iglesia. Conaculta-inaHM éx. Reproducción autorizada por el Instituto Nacional de Antropología e Historia. Foto: Pedro Ángeles, Archivo Fotográfico IIE-UNAM.

Incluso podemos considerar que desde la época de la conquista ya existía conciencia de este tipo de adquisición lexical; así, Fernández de 0 viedo, en I535, al utilizar gran cantidad de vocablos indígenas busca una disculpa, como nos hace notar M oreno de Alba, cuando dice:

bir su Pintura colonial en M éxico, utilice en la primera página de su libro, escrito en I935, al referirse a los orígenes de la pintura novohispana, un ejemplo lexical para explicarla; así, dice: “D ifícil es, para quien no se ha especializado en estudios prehispánicos, emprender un estudio acerca de la pintura anterior a la conquista, pero es necesario intentar ese estudio, como comienzo de todo nuestro movimiento pictórico: la cultura europea no se implantó de golpe; fue sustituyendo paulatinamente a las costumbres indígenas y en más de un caso el elemento aborigen predominó sobre el extranjero; así por ejemplo, la palabra tlapalería, con que se designa en la actualidad a los establecimientos en que venden colores y, por extensión, a las pequeñas ferreterías, es híbrida y se compone de tlapalli, palabra nahua que significa color, y de la terminación española ría, usada para indicar establecimientos comerciales. La persistencia de esta palabra hasta nuestros días indica cómo ciertos elementos del arte indígena persistieron durante toda la colonia y llegaron al mismo M éxico independiente." En M anuel Toussaint, Pintura colonial en M éxico, M éxico, Universidad N acional Autónoma de M éxico-Instituto de Investigaciones Estéticas-Imprenta U niversitaria, 1965, p. I. 


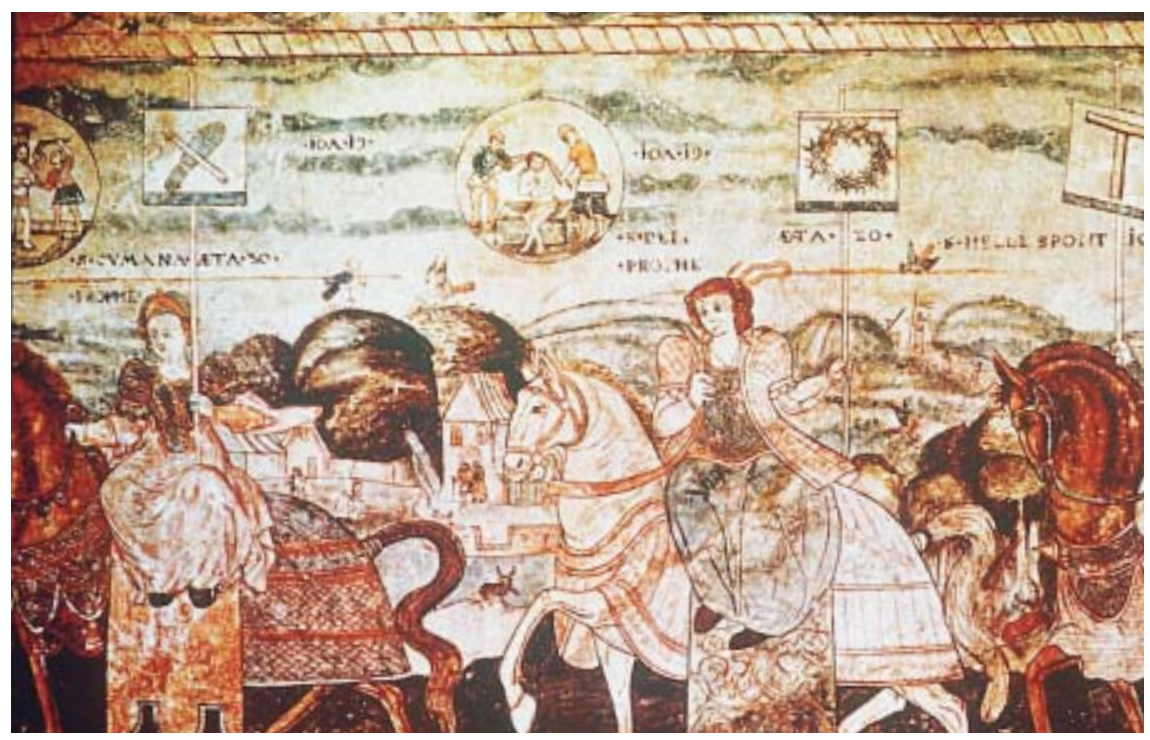

8. C asa del D eán, Puebla. M ural de las Sibilas. Conaculta-inaH-M éx. Reproducción autorizada por el Instituto Nacional de Antropología e H istoria. Foto: Guillermina Vázquez, Archivo Fotográfico IIE-UNAM.

si algunos vocablos extraños e bárbaros aquí se hallasen la causa es la novedad de que se tractan, y no se pongan a la cuenta de mi romance, que en $M$ adrid nascí y en la Casa Real me crié y con gente noble he conversado en algo he leído para que se sospeche que habré aprendido mi lengua castellana, en la cual de las vulgares se tiene por la mejor de todas, y lo que aviene en este volumen que con ella no consuenen, serán nombres o palabras puestos para dar a entender las cosas que por ellas quieren los indios significar. ${ }^{24}$

M uchas fueron las causas para este fenómeno de la sola persistencia lexical en la lengua española, pero vale la pena nombrar, entre ellas, la gran variedad de lenguas autóctonas que existían y su fragmentación; 25 la enorme facilidad

24. Citado por Moreno de Alba, op. cit., p. 84.

25. M oreno de Alba abunda sobre este tema y cita a Rosenblat, el cual dice: "la impresionante diversidad de lenguas - la llamada atomización lingüística de América - favorecía la imposición del español, única lengua realmente general. Pero allí donde pequeños núcleos de conquistadores y pobladores españoles se encontraron con poblaciones indígenas densas de cohesión cultural, social y política, la relación entre el español y las lenguas indígenas fue más 
por parte de los indígenas para aprender otras lenguas obró en contra de ellos mismos. A pesar de que, durante toda la época virreinal, tanto frailes como el grueso de la población usaban alguna lengua indígena, después de las independencias de los países americanos, por razones de "unidad nacional", fueron desapareciendo paulatinamente. El uso de los frailes de lenguas indígenas fue parte de las tácticas que se emprendieron para realizar la evangelización: "era más asequible que uno aprendiese la lengua de muchos que muchos la lengua de uno", pero también porque se daba dentro de una política de proteccionismo ante el temor de que los indígenas aprendieran, a través de la lengua, malos hábitos españoles, siendo así que, durante la evangelización, quienes se adaptaron al nuevo universo lingüístico fueron en realidad los españoles. ${ }^{26} 0$ tra razón que obró contra la permanencia de las lenguas indígenas, por contradictoria que parezca, fue la utilización de una lengua indígena como el náhuatl como lengua franca. ${ }^{27}$

Pero lo que queda al fin y al cabo, a pesar de este proteccionismo, es el avance del idioma español de forma arrolladora y no sólo por ser la lengua impuesta, sino también por el prestigio que otorgaba a quienes la hablaban, pues, como dice M oreno de Alba: "M ás que la ley, o la expulsión de los je suitas, el impulso del castellano se explica por otras causas: disminución de exploraciones y colonizaciones, el ascenso de los mestizos, partidarios como nadie de la lengua española, la influencia de la ilustración, etcétera." 28

Resulta inquietante el hecho de que las lenguas indígenas fueron conservadas durante el periodo virreinal y sólo reste de ellas un uso lexical; en cambio parecería que el lenguaje pictórico fue suplantado por completo desde los primeros años de la colonia.

compleja, y los problemas surgidos en la primera hora se prolongaron hasta hoy". M oreno de Alba, op. cit., pp. 70 y 77.

26. I bid., pp. 70, 72 y 76. La casi absoluta aniquilación de las lenguas indígenas se dio a partir de las guerras de independencia, ya que durante el gobierno español siguieron usándose con preferencia. Se ha dicho que en algunas zonas esta destrucción se dio a partir de la expulsión de los jesuitas. Además Carlos III, en 1770, expide su célebre Cédula de Aranjuez, en la que se ordena que "de una vez se llegue a conseguir el que se extingan los diferentes idiomas de que se usa en los mismos dominios (América y Filipinas) y sólo se hable el castellano". Parece que esta cédula se expidió por insistencia del arzobispo de M éxico, Francisco Antonio Lorenzana y Buitrón.

27. Ibid., p. 7I.

28. Ibid., pp. 75-76. 
¿Evolución precipitada?

Con un claro paralelismo con la lengua, los cronistas dan cuenta de la facilidad e inmediatez con la que los indígenas reproducían las convenciones figurativas occidentales; ya fray Jerónimo de $M$ endieta decía: " $M$ as después que fueron cristianos y vieron nuestras imágenes de Flandes y de Italia, no hay retablo ni imagen, por prima que sea, que no la retraten y contrahagan."29 D e la misma forma, el padre Las Casas aseveraba: "D e los oficiales que entre ellos había y hoy hay, pintores de pincel y el primor con que las cosas pintadas que quieren hacen, es ya tan manifiesto y claro, que será superfluo deciIlo por novedad, mayormente después que se dieron a pintar nuestras imágenes, las cuales hacen tan perfectas y con tanta gracia cuanto los más proprios oficiales de Flandes." 30

Las escuelas de artes y oficios de fray Pedro de Gante en San José de los $N$ aturales en San Francisco de la ciudad de M éxico, de Vasco de Q uiroga en Santa Fe, también en la ciudad de M éxico, y más tarde las experiencias en Tiripitío, M ichoacán, entre otras, hicieron bien su trabajo. D espués, la llegada de pintores europeos y la utilización de grabados hicieron el resto. Pero cabría preguntarse: ¿Por qué si las lenguas indígenas se usaron de forma ge neral hasta la época de la I ndependencia, y desde luego en forma parcial hasta nuestros días, la creación de imágenes en el lenguaje figurativo indígena no tuvo la misma persistencia (o resistencia)? D esde luego debemos tener en cuenta que se conservó por un tiempo, a través de los códices hechos después de la Conquista, pero éstos son considerados escritura, es decir, serían equival entes a la forma de registro de un lenguaje verbal, aunque tienen una gran comunidad figurativa con la pintura, lo que representa un problema aparte. También sabemos que el temor religioso a las imágenes indígenas siempre estuvo presente, sobre todo porque para los hombres del Renacimiento era evidente su fuerza; el mismo Leonardo había escrito en su Tratado de la pintura, preguntándose cuál era el monstruo más dañino, el ciego 0 el mudo, y su respuesta era contundente: "EI nombre de D ios escrito sobre

29. Fray Jerónimo M endieta, H istoria edesástica indiana, M éxico, Díaz de León y White, I870, p. 404. Citado por M anuel Toussaint, Pintura colonial en M éxico, M éxico, U niversidad Nacional Autónoma de M éxico-Instituto de Investigaciones Estéticas, 1965, p. Io.

30. Fray Bartolomé de las $C$ asas, A pologética historia de las Indias, M adrid, I909, cap. LXI, pp. 159-6I. Citado por Toussaint, op. cit., p. 22. 


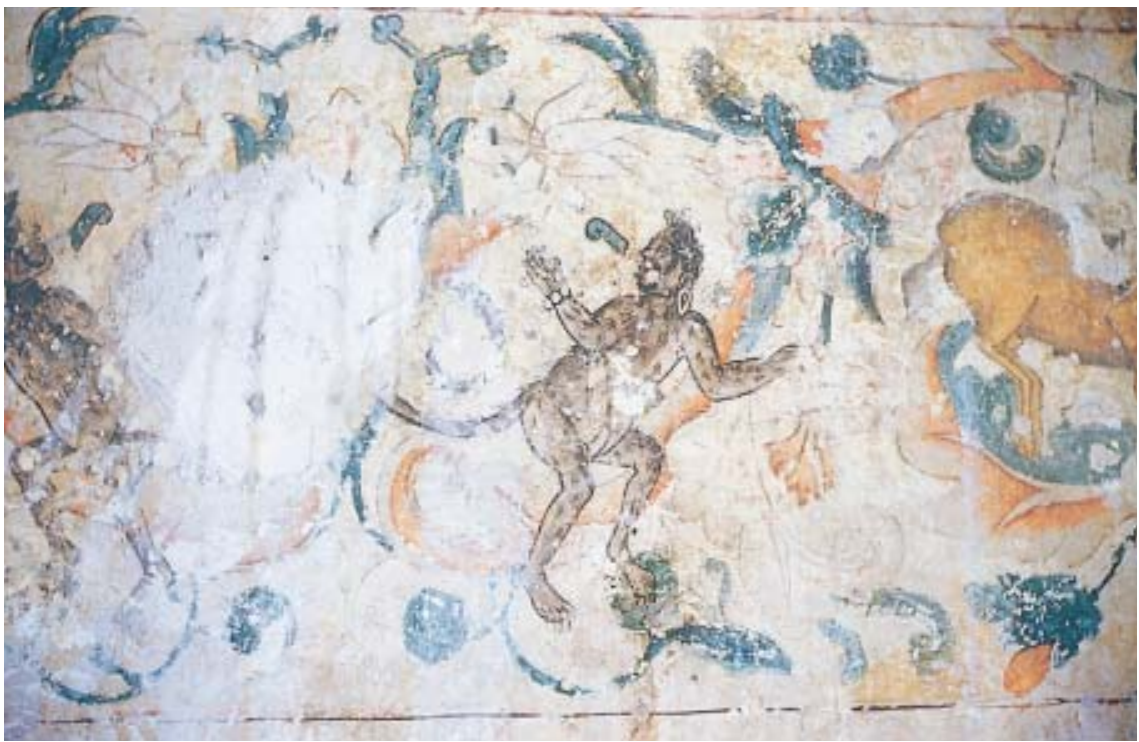

9. Casa del D eán, Puebla. Cenefa del mural de las Sibilas. Conaculta-inAH-M éx. Reproducción autorizada por el Instituto N acional de Antropología e H istoria. Foto: Raúl Flores G uerrero, Archivo Fotográfico IIE-UNAM.

una pared es menos venerado que su imagen." Este temor a las imágenes paganas persistió incluso hasta el mismo Siglo de las Luces, como puede comprobarse en los escritos de León y $\mathrm{G}$ ama, donde se abunda sobre la clasificación de éstas. ${ }^{3 \mathrm{I}}$ Pero también pueden existir respuestas diferentes y más simples, más allá del temor religioso y el sometimiento imperial.

Es evidente que, como primer impacto, las características de la pintura indígena, que a través de sus vestigios podemos observar, la hacían diferente a la producida por los europeos, ya que un análisis formal de ellas deja ver, en primera instancia, entre otras características: la ausencia de sombras emitidas por cuerpos opacos; la falta de leves gradaciones tonales para crear sutiles

3I. Antonio León y Gama, D escripción histórica y cronológica de las dos piedras, M éxico, Porrúa, 1978. Reproducción facsimilar de las primeras ediciones mexicanas, primera parte, 1792, segunda parte, I832. Véase también: Juana Gutiérrez H aces, "Las antigüedades mexicanas en las descripciones de don Antonio León y Gama", en XV Coloquio Internacional de H istoria del Arte Los discursos sobre el arte, M éxico, Universidad N acional Autónoma de M éxico-Instituto de Investigaciones Estéticas, 1995, pp. 12I-146. 
Io. Juan Gerson, El arca de Noé en el diluvio, temple sobre papel amate. Tecamachalco, Puebla. N ótese que el árbol que arrastra la corriente justo debajo de la barca tiene en su base un anillo como muchos jeroglíficos con esta forma. Conaculta-ınah-M éx. Reproducción autorizada por el Instituto $\mathrm{N}$ acional de Antropología e H istoria. Foto: Archivo Fotográfico IIE-UNAM.

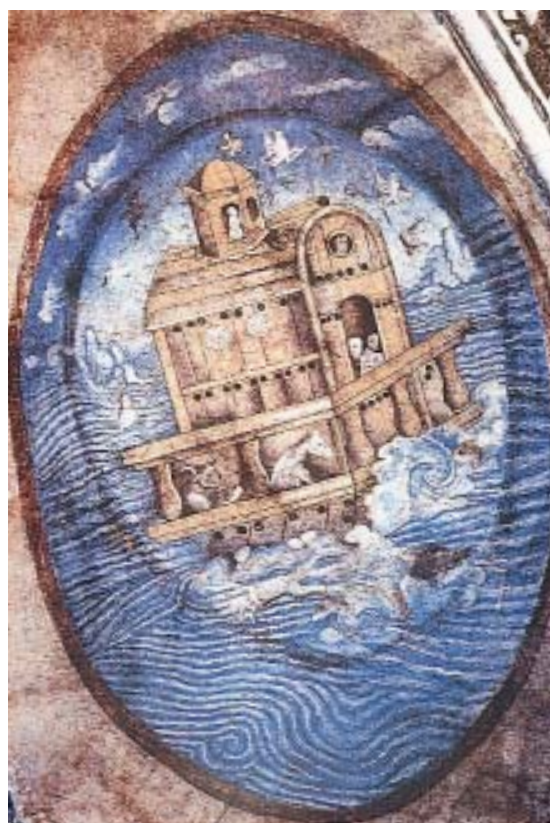

efectos de volumen en lo que parecería la utilización de colores enteros; las convenciones espaciales particularmente bidimensionales; en algunas ocasiones la falta de realismo al representar la figura humana, aunque esto es discutible - si no recuérdense, entre otras, las figuras de Bonampak.

Pero esta pintura también poseía características que no la hacían tan radicalmente diferente de la europea, como hemos afirmado: era figurativa y en ocasiones naturalista; ${ }^{32}$ en multitud de ocasiones las figuras poseían una carga simbólica muy fuerte, con significados no comprensibles para el espectador europeo, ${ }^{33}$ pero el mecanismo de abstracción simbólica no era ajeno a la

32. M endieta decía: "Pintores había buenos que pintaban al natural, en especial, aves, animales, árboles y verduras y cosas semejantes que usaban pintar en los aposentos de los señores. M as los hombres no los pintaban hermosos, sino feos, como a sus propios dioses... ", op. cit., p. 404. Es decir, debemos tener en cuenta que no sólo existía la pintura religiosa con un alto grado de abstraccionismo, sino también una profana, como la que había para adornar palacios, donde se hacía evidente el naturalismo e incluso la copia del natural.

33. M ás allá del significado particular de cada figura, debemos observar, como dice Gombrich: "el común denominador entre el símbolo y la cosa simbolizada no es la 'forma externa', 
DOI: http://dx.doi.org/10.22201/iie.18703062e.2002.80.2107

68

JUANA GUTIÉRREZ HACES

pintura religiosa europea; 34 la pintura europea tenía una larga experiencia en cuanto al hieratismo que mostraban las imágenes divinas indígenas, e incluso, dentro de la tradición visual que traía cada europeo, la ley de frontalidad también tenía acomodo; el dibujo o linealidad tenía una función básica en los dos sistemas de representación pictórica, y esto no es poca cosa, ${ }^{35}$ y los diversos soportes pictóricos también tenían su equivalencia en la pintura europea; algunos murales poseían, en cuanto al impacto decorativo dentro de un espacio arquitectónico, la misma función que en Europa tenían tantas capiIlas absolutamente pintadas desde los al bores del Renacimiento, y aun desde la Edad M edia, hasta los días de la conquista y colonización. Esta pasión de corativa indígena, según los cronistas, la trasladaron a las nuevas iglesias que les mandaban construir. ${ }^{36} \mathrm{D}$ esde luego caben las reservas, ya anotadas por in-

sino la función". "M editaciones sobre un caballo de juguete o las raíces de la forma estética”, en M editaciones sobre un caballo de juguete, Barcelona, Seix Barral, 1968, p. I5.

34. D e esto ya se ha hablado en varios estudios cuando se hace hincapié en al gunos actos religiosos como la comunión y otros cuyo significado no le era ajeno al indígena, sino incluso equivalente en algunos de sus ritos, por lo cual no es difícil pensar que en la creación de la imaginería se pudieran hacer adaptaciones similares. La feal dad de los dioses, a ojos de los españoles, no impide que el proceso de cargar simbólicamente a una figura fuera similar.

35. El uso del dibujo está a simple vista tanto en códices como en murales, pero también podemos citar a M otolinía cuando hace la descripción del uso de la plumaria y, para bien o para mal, y sea el resultado satisfactorio o no, el uso del dibujo es considerado como el "diseño", en el sentido que el Renacimiento le daba, pero también como parte de los diversos pasos de ejecución, como lo haría cualquier artista contemporáneo del otro lado del Atlántico, que también los habría malos y buenos, pero no por eso se invalidan sus procesos pictóricos: "y si alguna obra de esta ha ido a España imperfecta e las figuras e imágenes feas, halo causado la imperfección de los pintores que sacan primero la muestra y debujo, y después el amantécatl, que ansi se llamaba el maestro que asienta la pluma, [... ] si a estos amantecas les dan buena muestra de pincel, tal sacan otra de pluma; y como los pintores se han mucho perficionado 0 dan buenos debujos, hácense ya muy preciosas imágenes y mosaicos romanos de pluma y oro... " M emoriales, París, 1903, p. 9i. Citado por Toussaint, op. cit., p. i8.

36. "Pues si vamos al ornato de los templos, digo que es tan necesario entre estos indios, que me atrevo a afirmar que es una de las mayores partes de su devoción y conservación en la fe, porque eran tan dados a la curiosidad de ellos, que los había en todos los pueblos, así grandes como pequeños, muy hermosos y curiosos y adornados de toda la más hermosura que su entendimiento podía al canzar: y después de ser cristianos es tanto lo que ellos se han esmerado, que pone admiración. Esto digo de los que son de los Religiosos que los tenemos a cargo, porque para ello les hemos dado ripio a la mano, con que han seguido en sus edificios y adorno su natural inclinación, y así son las iglesias [... ] hacen mucho en ser tan buenas, llenas de altares, 
numerables autores de todos los siglos, respecto a que muchas de estas pinturas eran escritura donde la "narración" ocurría con otro sistema lingüístico.

Pero aun así, podemos concluir que, a pesar de al gunas diferencias formales, había intenciones, características y convenciones pictóricas que hacían a la pintura y a los pintores no sólo parecidos sino coincidentes al tratar, por ejemplo, algunos temas de corte más naturalista, ${ }^{37}$ pero incluso también algunos más conceptuales. Respecto a otras convenciones como la representación del espacio por medio de la perspectiva renacentista o la ausencia de sombras provocadas por cuerpos opacos, si bien la pintura indígena no las poseía, sí poseía otros sistemas espaciales que la hacían parecida a la pintura hecha por los europeos antes del Renacimiento; incluso podemos suponer, debido a esto, que al hacer los indígenas las primeras imágenes encargadas por los españoles los resultados no serían tan diferentes a algunas pinturas medievales o del temprano Renacimiento con las que pudieran estar familiarizados frailes y conquistadores; el mismo Toussaint (y no sólo él) habla de los parecidos con Cimabue, Giotto o con la escuela de Siena, probablemente refiriéndose $\mathrm{a} D$ uccio di Buonisegna. Aunque no es probable que algún fraile trajera consigo alguna imagen antigua (ya que estos pintores son de finales del siglo xir y principios del xiv y estamos hablando de la producción del siglo xvi), sí podríamos suponer que tuvieran algunas con dejos arcaizantes, pero más bien debemos pensar que sistemas similares de técnicas y convenciones pictóricas dan imágenes parecidas. Lo que sí cambiaba radicalmente eran los motivos y narraciones - los cuales marcaban las diferencias-, pero no cierta parte de las convenciones y prácticas pictóricas usadas. Así que, cuando se utilizan espacialidades bidimensionales, colores enteros, líneas como límite de una figura, los resultados deben ser parecidos para ambos sistemas de representación y no necesariamente hijos de la copia de obras del trecento. ${ }^{38}$

cuajadas de retablos de talla y de pincel y tan costosos que vale cada uno una gran suma de dineros." Códice M endieta, II, p. I74. Citado por Toussaint, op. cit., pp. I7-ı8.

37. Tanto para un pintor europeo como para uno indígena americano "el vocabulario convencional de formas básicas es siempre indispensable para el artista como punto de partida, como foco de organización", Gombrich, op. cit., p. 2I.

38. Gombrich, refiriéndose al uso de convenciones pictóricas, dice: "Para el investigador de los estilos, ese descubrimiento de que una misma forma básica puede representar una diversidad de objetos quizá llegue a ser todavía significativo. Pues mientras que resulta muy dura de tragar la idea de imágenes realistas deliberadamente sometidas a una 'estilización', en cambio, la idea opuesta, de que hay un limitado vocabulario de formas sencillas utilizado para cons- 


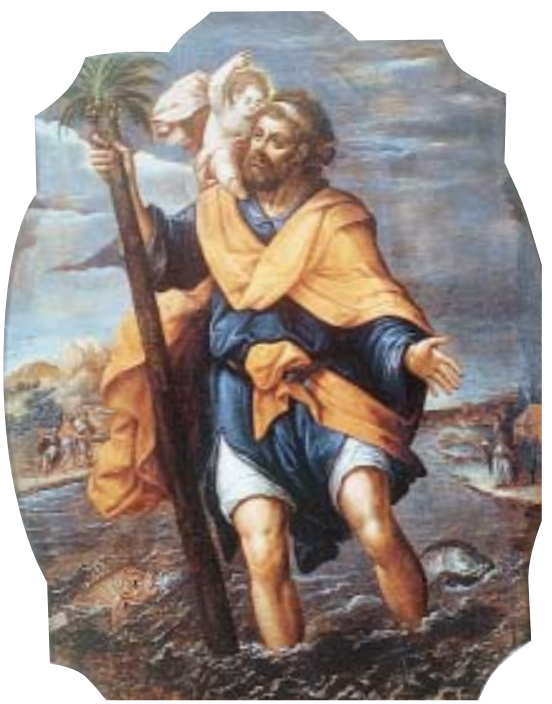

II. Simón Pereyns, San Cristóbal , C atedral de M éxico. Foto: Archivo Fotográfico IIE-UnAM.

M ás adelante, con la llegada de grabados de todas las épocas y estilos en uso en Europa, la adquisición de arcaísmos e innovaciones fue por la vía de la copia y aplicados, por analogía, a las nuevas producciones y en al gunas ocasiones sólo se confirmaba parte de un sistema ya conocido por los indígenas. Por lo tanto, debemos considerar que, en la primera producción pictórica, había dos tipos de convenciones técnicas: aquellas que de una u otra forma el indígena ya había practicado dentro de su sistema de representación y aquellas total mente nuevas que se le imponían de forma arbitraria dentro de la estructura formal de su lenguaje pictórico. Pero bastaría un solo tlacuilo queiniciara la innovación dela tridimensionalidad para considerar adoptada la convención, ya que a partir de la reducción que él hiciera se facilitaría la lectura y visión al resto de los pintores indígenas. Recuérdese que "un uso nuevo comienza siempre por una serie de hechos individuales" y, desde luego, "sólo en el momento en que una innovación, repetida con frecuencia, se graba en la memoria y entra en el sistema tiene el efecto de trastornar el equilibrio de los valores, y con ello se encuentra ipso facto y espontáneamente cambiada". 39

truir diferentes representaciones, encajaría mucho mejor con lo que sabemos del arte primitivo". Ernst H. Gombrich, M editaciones, op. cit., p. i9.

39. Charles Bally y Albert Sechehaye, al publicar el Curso de lingüística general de Saussure, 
I2. Simón Pereyns, Virgen del Perdón, parcialmente destruida en 1967, C atedral de M éxico. Foto: Archivo Fotográfico IIE-UNAM.

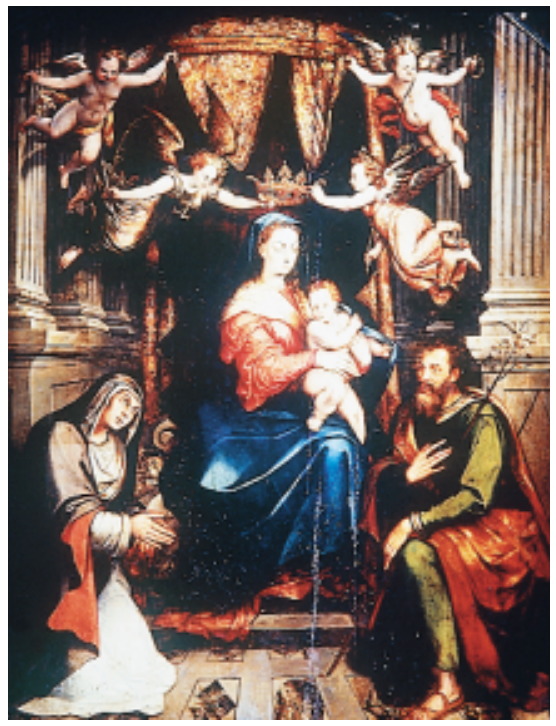

Cabe aclarar que debemos tener cuidado con las pinturas indígenas que se comparan, pues tenemos la tendencia a considerarlas un bloque estilístico estático del cual sacamos conjeturas, en lugar de pensar que también la pintura indígena evolucionó y no todo descubrimiento arqueológico-pictórico

hacen pocas anotaciones al margen sin embargo, ya que Saussure consideraba que las innovaciones del habla (no de la lengua) mientras siguen siendo individuales no habría que tomarlas en cuenta. Los editores aclaran que Saussure no hizo nunca lingüística del habla, por lo que ellos corrigen lo antes anotado arriba, diciendo: "que un uso nuevo comienza siempre por una serie de hechos individuales". Saussure, op. cit., p. 235. Sin embargo, al explicar Saussure, más adelante, las innovaciones analógicas (una forma analógica es una forma hecha a imagen de otra o de otras muchas según una regla determinada) dice: "todos los fenómenos evolutivos tienen una raíz en la esfera del individuo [... ] hizo falta que un primer sujeto lo improvisara, que otros lo imitaran y lo repitieran, hasta imponerlo en el uso", pp. 260 y 27I. De forma similar, en muchas ocasiones Gombrich afirma lo mismo respecto a los cambios de estilo, ya sea en su libro El arte y la ilusión o categóricamente en la entrevista con D idier Eribon cuando explica su larga lucha contra la idea del "espíritu de la época" diciendo: "M i fin era simplemente volver a un nivel más individual. He sido siempre muy crítico respecto a cualquier forma de colectivismo. No es una conciencia colectiva la que crea un estilo. $\mathrm{H}$ ace falta que al guien lo invente", en Ernst G ombrich y D idier Eribon, Lo que nos cuentan las imágenes, M adrid, D ebate, I992, p. 72. 
coincide con la "etapa" en la que debía encontrarse la pintura prehispánica en el momento de la conquista; y esto mismo reza para el arte llegado con los conquistadores y colonizadores, puesto que son asuntos básicos para entender con precisión la aceptación o rechazo de las convenciones europeas.

Por todo lo anterior, podríamos suponer que parte de la supuesta "eliminación" de la pintura indígena, si hubo tal, se debió a un motivo sencillamente "técnico". La pintura que traían los españoles se encontraba en un estadio de desarrollo diferente, para al gunos, se podría decir, más adelantado, pero no es cuestión de calificaciones culturales, sino de competencia tecnológica. Si, como dice Gombrich, la cultura occidental se ha constituido sobre la base de creer en el progreso y el arte europeo había seguido la regla de ensayo-rectificación en el avance hacia la creación de imágenes "convincentes" $4^{\circ}$ es evidente que podían considerar que las convenciones usadas por los indígenas y aprendidas en sus talleres debían, de ahí en adelante, seguir este esquema de progreso, y por lo tanto sólo habría que acelerar ese proceso, ponerlas al día añadiendo novedades tales como la perspectiva, el uso de sombras, etc. De esta forma, se llevarían las convenciones pictóricas indígenas a una "evolución precipitada" a partir del desarrollo técnico que poseían al momento de la conquista para igualarlo al español, por lo que, en estricto sentido, quizá no se debe hablar de la desaparición de la pintura indígena, sino sólo de un ajuste morfológico y paulatinamente de estilo; de ahí la transformación que sufre, pero no la desaparición absoluta de sus habilidades para hacer imágenes. D e cualquier modo, el rápido aprendizaje de estas nuevas convenciones nos parece sospechoso, incluso hasta pensar, como lo hacen los lingüistas, que ante una súbita revolución que altera las normas seguidas secularmente en un plazo relativamente breve "suele ser necesario suponer una larga 'vida latente' del fenómeno, anterior a su eclosión". ${ }^{4 I}$ Con

40. La creación de "imágenes convincentes" está unida al principio de "testigo ocular" explicado por Gombrich, en el cual no sólo son importantes los avances técnicos, sino la posición de la sociedad hacia la imagen realista; en especial Gombrich explica la participación de la I glesia, en la que en buena parte tuvieron que ver órdenes como franciscanos, dominicos, etc., y la moderna forma de predicar que tuvo que ver con la revolución de la imaginación y la creación de imágenes durante el Renacimiento y el Barroco. Gombrich y Eribon, op. cit., pp. 68 y ss.

4I. Ramón M enéndez Pidal, "Sevilla frente a M adrid. Algunas precisiones sobre el español de América", en M iscelánea homenaje a André M artinet. Estructuralismo e historia, D iego C atalán (ed.), Universidad de La Laguna (C anarias), I957, vol. III, p. 99. 
esto no quiero decir que la pintura indígena estuviera, por ejemplo, preparando la entrada de la perspectiva lineal a su pintura, eso nunca lo sabremos, pero sí que existía un sistema de representación espacial, para el momento bidimensional, que los preparaba mental, conceptualmente, para entender un agregado más, como sería la tercera dimensión, que completaría, una vez asimilados los nuevos esquemas, una imagen espacial de "la realidad" totalmente novedosa.

D ebido a que los cambios en la forma de pintar se dieron por ajustes técnicos a través de la enseñanza iniciada por los frailes, el indígena pudo con rapidez dar excelentes resultados, ya que tenía las bases del oficio suficientes para entender las nuevas propuestas 0 , por lo menos, la habilidad para copiarlas y así conseguir los mismos efectos que tenían los modelos españoles, como lo atestiguan con admiración los cronistas del siglo xvi ya nombrados. Así, Sahagún puede decir:

El pintor en su oficio sabe usar de colores y debuxar o señalar las imágines con carbón, o hacer buena mezcla de colores, y sabellas bien moler y mezclar. El buen pintor tiene buena mano y gracia en el pintar, e considera muy bien lo que ha de pintar, y matiza muy bien la pintura, y sabe hacer las sombras y los lexos, y pintar los follajes. El mal pintor es de malo y boto ingenio, y por esto es penoso y enojoso, y no responde a la esperanza del que da la obra, ni da lustre en lo que pinta, y matiza mal. Todo va confuso; ni lleva compás o proporción lo que pinta, por pintallo de priesa. $4^{2}$

Como se ha hecho notar, es evidente que Sahagún está hablando de los pintores contemporáneos, ya que habla de sombras, pero no sólo eso llama la atención, pues al utilizar la palabra lexos y proporción se sugiere el uso de la perspectiva y la ley de la proporción ligada a ella; al usar matiza supone la disolución de los colores enteros, no sólo para permitir transparencias, sino también ilusión de volúmenes; y la palabra confuso vendría a significar que la norma es la composición ordenada. Para nuestros fines es importante dicha cita, pues demuestra lo que ya poseían técnicamente los artistas indígenas y

42. Fray Bernardino de Sahagún, H istoria general de las cosas de N ueva España, introducción, paleografía, glosario y notas de Alfredo López Austin y Josefina García Q uintana, M éxico, Consejo N acional para la Cultura y las Artes-Alianza M exicana, I989, pp. 596-597. Las cursivas son mías. 


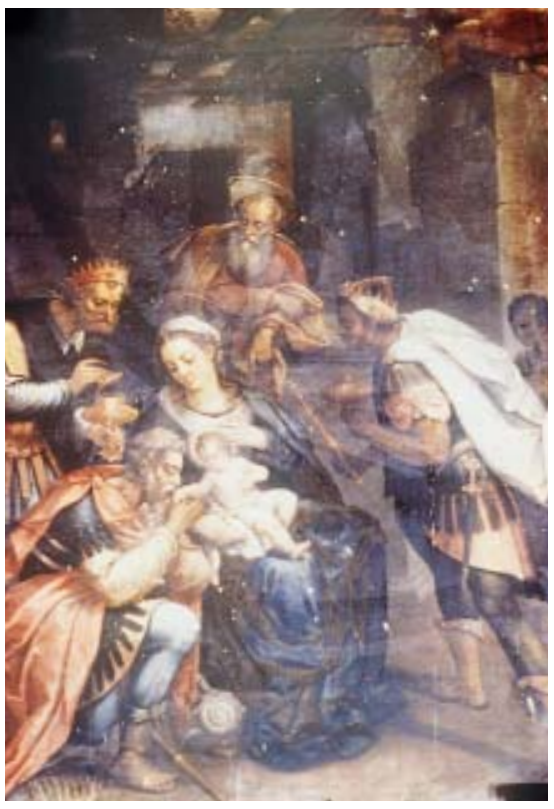

I3. Simón Pereyns, Adoración delos Reyes, retablo mayor del convento de Huejotzingo. Conaculta-INAH-M éx. Reproducción autorizada por el Instituto Nacional de Antropología e H istoria. Foto: Pedro Ángeles, Archivo Fotográfico IIE-UNAM.

lo que estaban adquiriendo, sin que se hiciera evidente, para el cronista, que hubiera demasiada diferencia entre unas y otras prácticas, lo que sólo viene a probar, de nuevo, la pronta asimilación de las novedosas técnicas "impuestas". ${ }^{43}$ Además, debemos recordar que, al fundar los frailes las escuelas de artes y oficios, tuvieron muy en cuenta la tol tecáyotl, es decir, la maestría en las artes mecánicas, aprendidas por la nobleza indígena en el calmécac. ${ }^{44}$

Es evidente que no todo el fenómeno de adquisición de un nuevo lenguaje pictórico queda explicado; ésta es simplemente una hipótesis que quizá pueda ser aplicada sólo en parte, pero sirve para formular de nuevo la serie de preguntas que necesita el estudio de nuestro arte virreinal. Además, debemos considerar que esta adaptación técnica tuvo sus tropiezos; por ejemplo, veamos lo que escribe el virrey Velasco en I552:

43. La conservación de muchas de las técnicas indígenas en las escuelas misionales ha sido notada por Elena Isabel Estrada de G erlero en "Las utopías educativas de G ante y Q uiroga”, en El otro $O$ ccidente. L os orígenes deH ispanoamérica, M éxico, Teléfonos de M éxico, 1992, p. II7.

44. Elena I sabel Estrada de Gerlero, op. cit., pp. Iıo-I4I. 
I4. Simón Pereyns, Adoración de los pastores, retablo mayor del convento de Huejotzingo, Puebla. Conaculta-INAH-M éx. Reproducción autorizada por el Instituto Nacional de Antropología e Historia. Foto: Archivo Fotográfico IIE-UNAM.

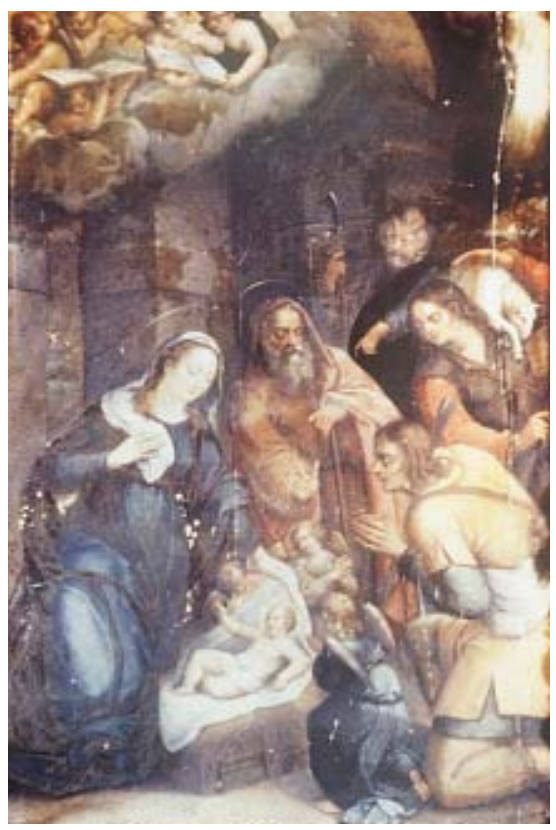

Por cuanto soy informado que algunos indios pintores, así de la parte de M éxico como de Santiago, pintan imágenes así en sus casas como en otras partes, los cuales como no están examinados hacen dichas imágenes sin aquella perfección que se requiere en oprobio y de servicio de D ios N uestro Señor, por lo cual conviene que ningún indio, no pinte las dichas imágenes sin que primeramentes sean examinados y los que hubieren de pintar, sean en la capilla de San José del convento de San Francisco de esta ciudad. ${ }^{45}$

Es decir, no se les impide hacerlas, sino sólo deben cumplir con una serie de medidas que, aseguran, harán que las imágenes se produzcan en forma correcta, esto es, siendo examinados, y así poner a prueba la asimilación de los elementos nuevos y hacerlas dentro de un plantel que vigile y proteja el de coro y fidelidad de las formas. Podríamos decir, para el caso de los indígenas involucrados, parafraseando a Gombrich, que probablemente "el vocabulario 
relativamente rígido de la tradición (prehispánica) operaba como una pantalla selectiva que sólo admitía los rasgos para los que disponía de esquemas", ya que los artistas "tienden a buscar motivos para los cuales su estilo y su adiestramiento les han equipado". ${ }^{46}$ Para vencer estas dificultades iniciales estaban las escuelas de Gante y de Q uiroga, que adiestraban y enseñaban nuevos esquemas y los agregaban a aquellos con los cuales ya contaban. Pero aun habiendo estos escollos no se invalida el hecho de la pronta asimilación del nuevo vocabulario, por arbitrario que fuera parte de él dentro de su sistema de representación.

Lo anterior podría hacer pensar que este vocabulario hizo desaparecer totalmente lo que consideraríamos el "estilo indígena", lo cual es discutible, puesto que aún en el siglo xviı se sigue nombrando este estilo, para calificar tanto obras del pasado 47 como obras contemporáneas. Es posible que, a pesar del ajuste técnico, el cambio de hábitos visuales y la total asimilación al vocabulario pictórico español en los siglos posteriores, siguiera habiendo un estilo indígena, el cual, para el caso novohispano, somos incapaces de identificar actualmente, pero que no debemos confundir con "la mano indígena", que sólo muestra una filiación racial del ejecutor y no un estilo; ni tampoco lo podemos confundir con expresiones populares que presentan otros problemas que no discutiremos aquí.

En lo que respecta a la apropiación de formas técnicas, pero que tienen la virtud de ser a la vez simbólicas, como la perspectiva, podemos suponer que se aprendieron primero como parte de la geometría (como aún hoy), y la conceptualización espacial se hizo más pausadamente y por diversos caminos que implican la asimilación de toda una cultura, no sólo visual.

N o obstante la pronta asunción de nuevas técnicas pictóricas, por un bre-

46. Reflexión que se hace Gombrich al hablar sobre un artista chino que pinta paisajes ingleses en E.H. Gombrich, Artee ilusión, Barcelona, Gustavo Gili, 1979, p. 86.

47. El caso más evidente, aunque no único, es el del ayate de la Virgen de Guadalupe, que el mismo M iguel Cabrera asegura que está pintado en el estilo de los indios; considero que tal afirmación no es sólo un recurso retórico. Cabrera escribe: "y el avernos dexado nuestra D ulcissima M adre esta milagrosa M emoria, bellísimo Retrato suyo, parece que fue adaptarse a el estilo, o lenguaje de los indios; pues como sabemos, no conocieron ellos otras escrituras, Sylabas o Frases mas permanentes, que en expresivos symbólicos, o geroglíficos del pincel". Véase $\mathrm{M}$ iguel Cabrera, M aravilla americana y conjunto de raras maravillas observadas con la dirección de las reglas de la pintura en la prodigiosa imagen de Nuestra Señora de Guadalupe de M éxico, M éxico, Imprenta del Real y más Antiguo Colegio de San Ildefonso, 1756, p. 29. 
ve periodo, que con gran effuerzo podríamos al argar hasta finales del siglo xvI y principios del xvir, coexistieron, mezclados, al gunos rasgos indígenas evidentes con las convenciones pictóricas españolas; esto es particularmente visible en algunas de las pinturas murales del siglo xvi que han sobrevivido. $4^{8}$

\section{Préstamos lexicales}

Al estudiar la pintura del siglo xvi tenemos que separar y no confundir lo quees un proceso de adquisición de un lenguaje pictórico ajeno, que avanza a través de prueba y error, y lo que es la introducción de elementos "puros" del mundo indígena. Así, los toscos intentos de entender la perspectiva no son un elemento indígena aplicado a una solución pictórica europea, sino un difícil camino de incomprensiones, pero también de aprendizaje, ya que no se trataba sólo de re presentar la profundidad sobre el plano, sino de entender una nueva estructura del universo, no naturalista ni científica, sino cultural; lo mismo podríamos decir dela luz local, del claroscuro y, desde luego, de las sombras emitidas, sólo por mencionar algunos procesos de aprendizaje cuyas toscas interpretaciones de ninguna manera son elementos indígenas, sino eso, procesos de aprendizaje que, como dicen los cronistas, fueron alcanzados con gran rapidez y talento. Sin embargo, aparte de este ajuste técnico, no podemos negar la inclusión de ele mentos netamente indígenas, es decir, formas de su universo figurativo como, por ejemplo, sólo por nombrar algunas, en las pinturas del sotocoro deTecamachalco, pintadas supuestamente por el tlacuilo Juan Gerson, donde se pueden observar claramente estos elementos, como bien ha señalado Pablo Escalante, 49 al percibir un glifo de topónimo entre los objetos arrastrados por la corriente de agua del diluvio. I gual sucede con las pinturas que sobre Sibilas y Los TriunfoS dePetrarca mandara hacer el deán don Tomás dela Plaza en su casa en la ciudad de Puebla; particularmente me refiero a al gunos motivos en las cenefas de ambas habitaciones, como, por ejemplo, los monos o changuitos con vírgula de la pa-

48. Aunque dentro de esta discusión tienen un papel importante los códices, los haremos por el momento a un lado, sobre todo por lo ya dicho, que, siendo como son registros de otro sistema lingüístico, merecerían una digresión aparte.

49. Pablo Escalante, "Fulgor y muerte de Juan Gerson o las oscilaciones de los pintores de Tecamachalco", ponencia presentada en el XXVI Coloquio Internacional de H istoria del Arte. El proceso creativo, celebrado en Saltillo, C oahuila, en diciembre de 2003. 


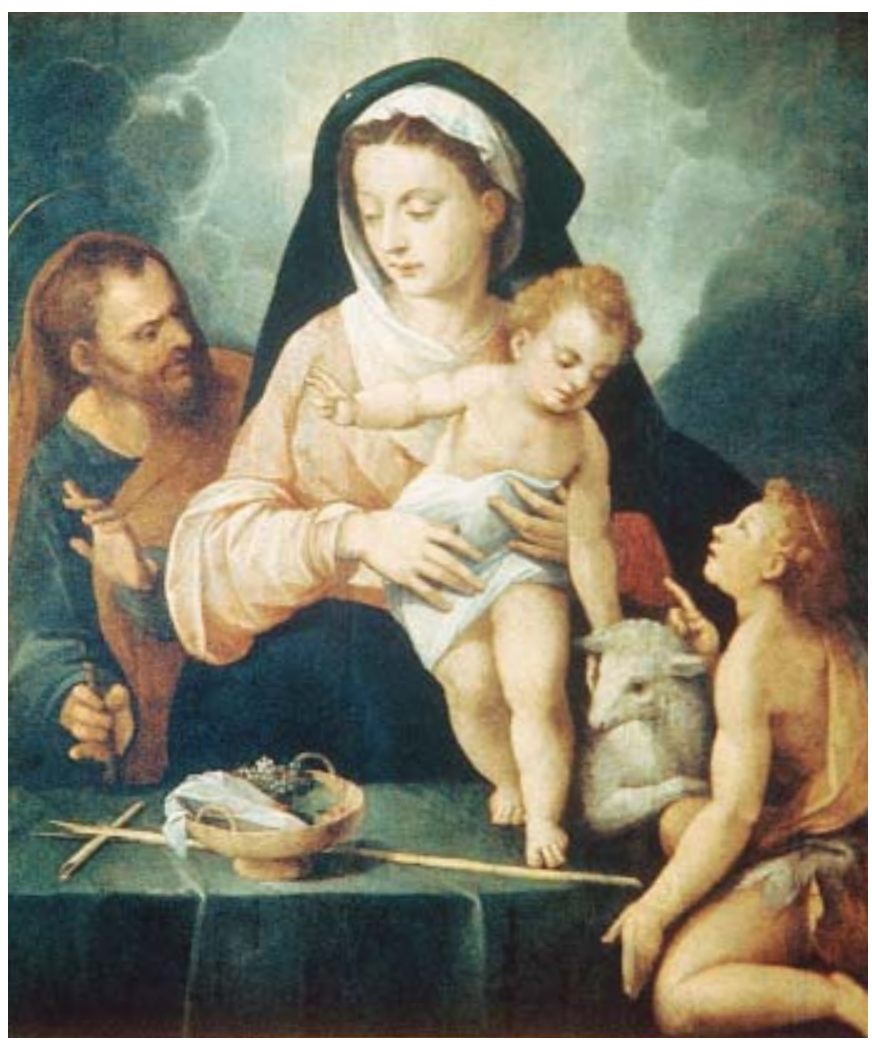

I5. Andrés de Concha, Sagrada familia, M useo N acional de Arte. Foto: Elisa Vargaslugo, Archivo Fotográfico IIE-UnAM.

labra a la usanza indígena que acompañan a las Sibilas. Sin embargo, parecerían suceder, a semejanza del estudio de la lengua española en América, que sólo son

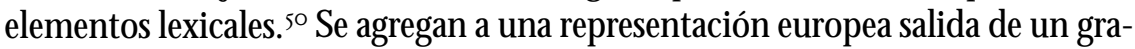

5o. Elena Lozanova, op. cit., nota 7, p. 62, observa: "Los préstamos se caracterizan por los siguientes rasgos: son elementos aislados e independientes que otras lenguas adoptan fácilmente y frecuentemente; la introducción de estos elementos no afecta a la estructura de la lengua que los toma prestados; usualmente los recibe; las lenguas tienden a seleccionar de aquellas zonas de la lengua extranjera que, al menos exteriormente, se correspondan de una manera aproximada con esas mismas zonas en su propia lengua; tendencia al ajuste mínimo."

El hecho de que los préstamos lexicales observados en estas pinturas sean un "mono" o el glifo de un topónimo afirma el hecho de que sólo sean lexicales los préstamos, ya que, como dice 


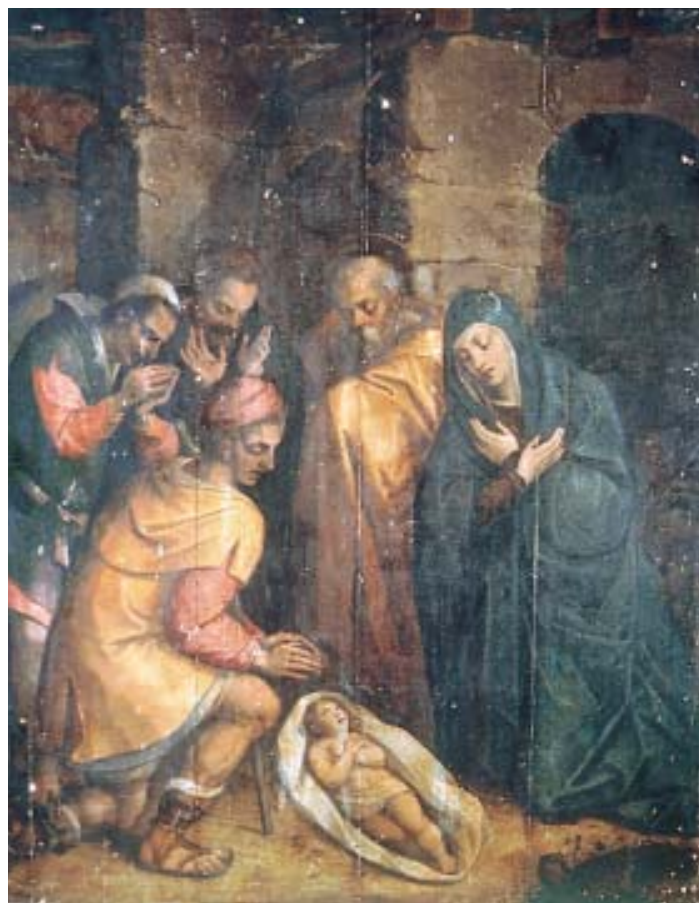

I6. Andrés de Concha, Adoración de los pastores, convento de Yanhuitlán, O axaca, retablo mayor. Conaculta-INAHM éx. Reproducción autorizada por el Instituto N acional de Antropología e Historia. Foto: Pedro Ángeles, Archivo Fotográfico IIE-UNAM.

bado y seguida, incluso, con gran minuciosidad, pero no alteran la composición; si son sólo eso: vocabulario introducido en un texto "extranjero". ${ }^{52}$

Lozanova: "El método del estudio del léxico de una lengua conocido como 'palabras y cosas' parte de la observación de que muchas palabras, al paso de una lengua a otra, circulan siempre unidas a las cosas que denominan. Por consiguiente, la etimología de la palabra se estudia paralelamente a la historia de la cultura; el discurso verbal es un discurso cultural porque crea un enlace entre el hombre y su entorno humano y cósmico." O p. cit., nota io, p. 63.

5I. Saussure, op. cit., p. 69, nos recuerda: "Pero ante todo, las palabras de préstamo ya no cuentan como tales préstamos en cuanto se estudian en el seno del sistema; ya no existen más que por su relación y su oposición con las palabras que les están asociadas, con la misma legitimidad que cualquier signo autóctono."

52. La investigadora Alessandra Russo tiene sus reservas, sobre todo ante la creación de imá- 
DOI: http://dx.doi.org/10.22201/iie.18703062e.2002.80.2107

80

JUANA GUTIÉRREZ HACES

D esde luego, al igual que los lingüistas, se deberá tener en cuenta el real peso demográfico y social de la población indígena en los casos analizados y su "sistema de representación", lo mismo que aquel que los españoles de la región estudiada traen consigo, ya que la inclusión de elementos indígenas deberá ser considerada sólo cuando no resulten explicables en los usos de representación española, y partiendo del hecho de que el estudio no puede ser unilateral, porque las innovaciones y cambios tienen una importancia equivalente en ambos sistemas, 53 lo que dará como resultado mayor facilidad al buscar el origen de los cambios, pues éstos dependerán de su desarrollo en el tiempo y no de la geografía en la que se den. Lo anterior nos lleva más que nunca a conocer y analizar la pintura indígena, la pintura española, o la flamenca o la italiana para no incurrir en algunos errores que tuvieron los lin-

genes con la técnica de la plumaria. Sin embargo, reconociendo la problemática, ya que las plumas tenían un significado específico para la cultura indígena, si tomamos, por ejemplo, la representación del Salvatore mundi en plumas, este hecho no altera el que sea el Salvatore mundi de la tradición cristiana, ya que está "pintado" como los europeos utilizando las plumas en lugar de pinceladas, lo que podría equivaler a que éstas son una parte externa del lenguaje; son sólo medio de transmisión y no parte del lenguaje interno, pues no existen en la figura cambios morfológicos y sintácticos [formas y relaciones]. El "pintar con plumas" puede agregar contenido simbólico, pero eso pertenece a la iconografía del cuadro, no a su composición formal. Saussure nos recuerda con un ejemplo muy cercano a nuestro problema que: "Para la lingüística interna la cosa es muy distinta: la lingüística interna no admite una disposición cualquiera; la lengua es un sistema que no conoce más que su orden propio y peculiar [... ] interno es todo cuanto concierne al sistema y sus reglas. Si reemplazo unas piezas de madera por otras de marfil, el cambio es indiferente para el sistema; pero si disminuyo o aumento el número de piezas, [la comparación es a partir de un juego de ajedrez] tal cambio afecta profundamente a la 'gramática del juego'", op. cit., p. 7o. Por otra parte, el valor de las plumas estaría ligado a una conexión asociativa in absentia en una serie mnemónica, y no a la sintagmática in praesentia, apoyándose en dos o más términos presentes en una serie efectiva. Saussure, op. cit., pp. 207-213. El mismo Saussure nos da de nuevo un ejemplo ligado al arte: "D esde este doble punto de vista una unidad lingüística es comparable a una parte determinada de un edificio, una columna por ejemplo; la columna se halla, por un lado, en cierta relación con el arquitrabe que sostiene; esta disposición de dos unidades igualmente presentes en el espacio hace pensar en la relación sintagmática; por otro lado, si la columna es de orden dórico, evoca la comparación mental con los otros órdenes (jónico, corintio, etc.), que son elementos no presentes en el espacio: la relación asociativa", p. 208. Es así que el uso de la pluma, al igual que el uso del orden dórico, evoca un significado no presente en la representación por ser asociativo, que no transforma de ninguna manera la representación física del Salvatore mundi. Sin embargo, reconocemos que está abierta la discusión y que es pronto para sacar conclusiones.

53. Saussure, op. cit., p. 315 . 
güistas que, por ignorancia, para ese momento de la lingüística histórica, consideraron como indígenas fenómenos que ya preexistían en el español.54

El ejemplo tomado de la casa del deán, antes mencionado, lo podemos considerar paradigmático en la inclusión lexical en el lenguaje pictórico europeo, ya que el patrón de la obra era un hombre que por su cultura debió estar consciente de esta inclusión, de la misma manera que lo estaban los conquistadores, empezando con Colón, al añadir palabras nuevas en las cartas que le escribían al rey, no sólo como bautizo de los objetos desconocidos, sino porque el uso de estos indigenismos daba "estatus" a aquel que los usara convirtiéndolos en "conquistadores viejos", es decir, aquellos que estuvieron desde las primeras hazañas de la conquista.

D on Tomás de la Plaza, deán de T laxcala, en una carta escrita a su hermano en la Puebla de los Ángeles el 9 de marzo de 1574 , hace evidente que pertenece a una familia escolarmente cultivada y que sigue en su escribir "una norma de ribetes arcaizantes" pero que revelan también "su asimilación al habla americana tímidamente reflejada". 55 Es decir, en este personaje se empiezan a vislumbrar características en el habla que después serán comunes en el español americano, por lo cual es interesante observar cómo paralelamente

54. Fontanella, op. cit., p. 29. Fontanella especialmente cita el estudio de B. Malmberg: "L'espagnol dans le N ouveau M onde, problème de linguistique générale", al igual que Amado Alonso, op. cit., pp. 320-32I.

55. Juan Antonio Frago García, H istoria del español de América, M adrid, Gredos, I999, pp. $5 \mathrm{I}^{-} 52$. Según observa el autor, el americanismo al que se refiere es al uso de lo que los lingüistas denominan el fenómeno de las ceceantes-seseantes: aunque admite que tendría que ver el trazo de la "ese final" de la palabra en cuestión en el manuscrito original, dichos rasgos han sido identificados por al gunos como influencia andaluza; para otros es más vasto el campo de este uso en España, pero lo que importa es que se convierte en característico del habla americana. Respecto a los ribetes arcaizantes en la forma de hablar del deán, también Zamora Vicente, citado por M oreno de Alba, op. cit., p. 22, opina: "el fondo patrimonial idiomático (del español americano) aparece vivamente coloreado por el arcaísmo y por la tendencia a la acentuación de los rasgos populares". El citado documento del deán de T laxcala está incluido en Concepción Company Company, D ocumentos lingüísticos de la N ueva España. Altiplano central, M éxico, Universidad N acional Autónoma de M éxico, 1994. Estos elementos, aun cuando una carta es poco para juzgar, nos acercan de alguna forma a no extrañarnos de que en los murales que encarga para su casa haya motivos indígenas. La cultura del deán, por otra parte, nos hace suponer que podía considerar como normal la admisión de estos elementos como una nueva integración a la cultura judeocristiana romana, actitud bastante normal en los hombres del Renacimiento. 
82

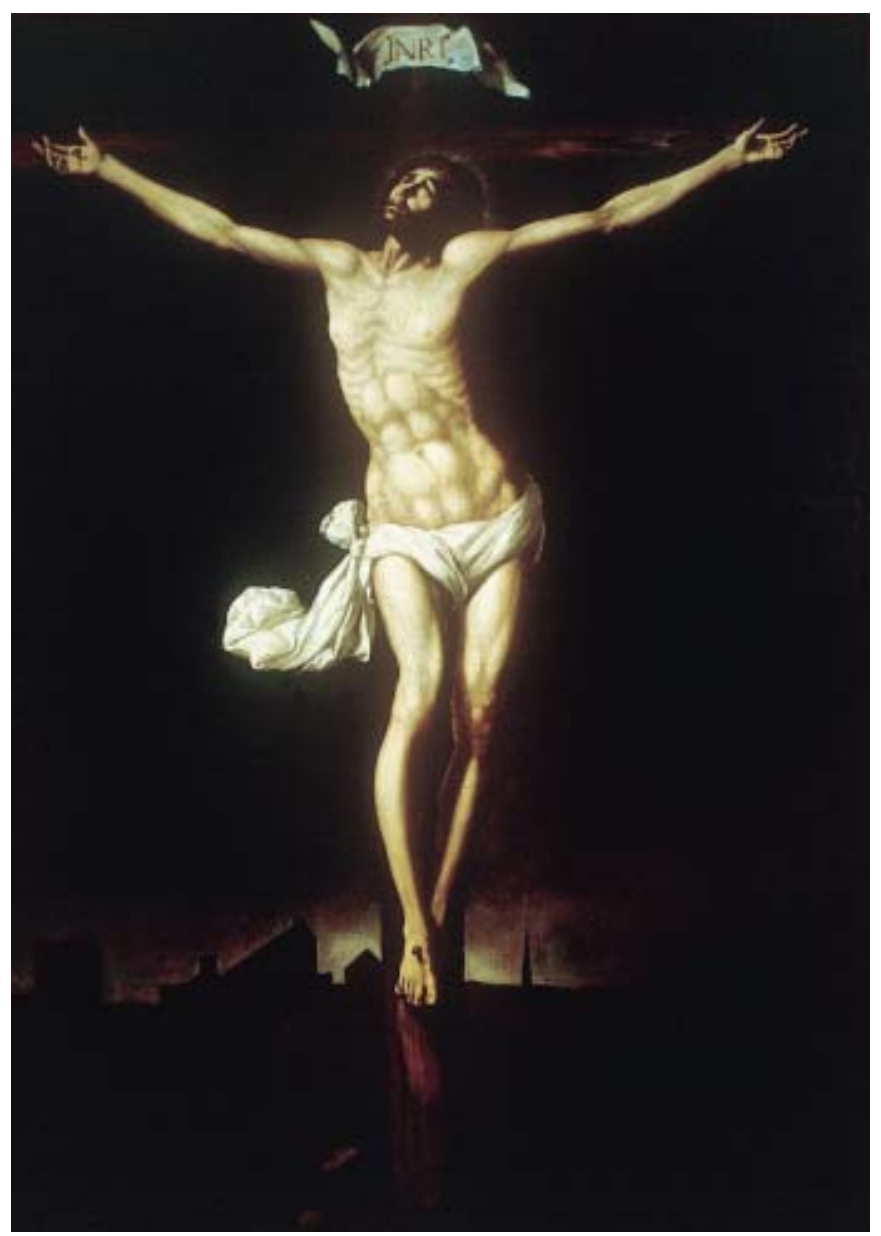

17. Sebastián López de Arteaga, Crucifixión, M useo Nacional de Arte. Foto: Pedro Ángeles, Archivo Fotográfico IIE-UnAm.

ocurre el mismo fenómeno con lo que manda pintar en los salones de su casa de Puebla y en su habla.

0 tro elemento a tomarse en cuenta, al analizar los préstamos lexicales en la pintura, es observar la vitalidad de esteléxico indígena, para posteriormenteentender su rápida desaparición en la pintura de los siglossiguientes; aunque en el xviII, por razones políticas, al gunas pinturas se cargan de símbolos reivindica- 
I8. Sebastián López de Arteaga, La incredulidad de Santo Tomás, Museo Nacional de Arte. Foto: Pedro Cuevas, Archivo Fotográfico IIE-UNAM.

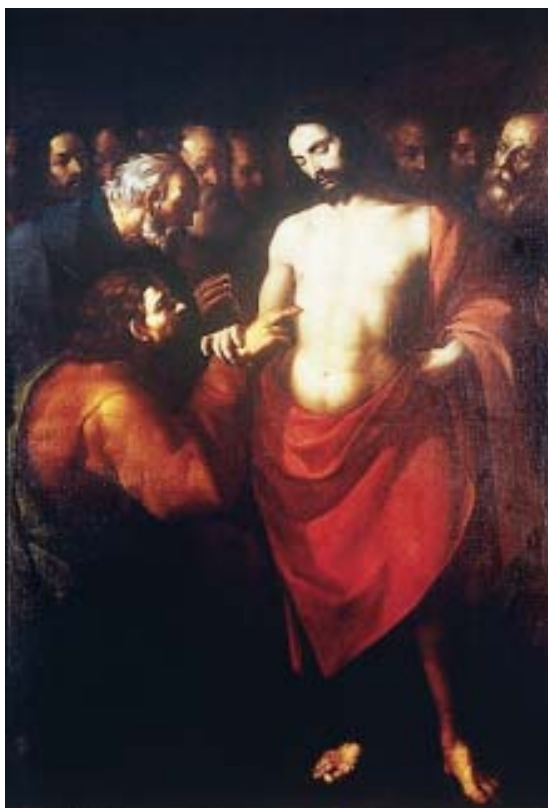

dores de los indígenas, pero éstos se hacen ya en lenguaje pictórico novohispano, a partir del tema y la narración, y no con préstamos lexicales indígenas.

El tema dela influencia indígena sobre "loslenguajes" pictóricosimportados, usando los avances de la lingüística, merece toda una investigación particular y abundantes digresiones; sólo adelanto estas dudas e hipótesis con el ánimo de que esto sirva de antecedente y con la certeza de que los estudios de la lingüística podrán aportar mucha luz a nuestra historia de la pintura en el siglo xvı.

Nivelación como proceso generalizador

Al estudiar los usos de representación de lo que conocemos como "escuela española", nos damos cuenta de que, a pesar de marcar como exclusivamente lexical el uso de determinados indigenismos durante el siglo xvi y señalar su pronto abandono, a partir del siglo xvir la pintura novohispana va adquiriendo una personalidad que la distingue de la que se desarrolla en España. Esto también lo podemos analizar por medio de los estudios hechos sobre la lengua española en América, y es a través del concepto de nivelación. 
DOI: http://dx.doi.org/10.22201/iie.18703062e.2002.80.2107

84

JUANA GUTIÉRREZ HACES

La nivelación es la reducción consciente 0 inconsciente de elementos heterogéneos para lograr una determinada homogeneidad. ${ }^{66} \mathrm{~L}$ a idea de nivelación utilizada por los lingüistas para explicar el español en América tiene su origen en las ideas de Saussure en el capítulo dedicado a la propagación de las ondas lingüísticas, explicada a través de la "fuerza del intercambio" y "el espíritu de campanario".57

Fue Amado Alonso uno de los primeros en utilizar el término "nivelación" y lo explica "como una renuncia a los particularismos propios y aceptación de los ajenos en el marco evolutivo del 'modo americano de vida', es decir se acoge a la 'fuerza del intercambio'". Alonso añade: "La base del español americano es la forma americana que fue adquiriendo en su marcha natural el idioma que hablaban los españoles del siglo xvi, los de isoo y los de I60o, y unos decenios del xvir." ${ }_{58}^{8} \mathrm{D}$ e igual manera, la pintura novohispana tendrá como base la forma americana que fue adquiriendo en su marcha natural la pintura que fue traída a estas tierras durante el siglo xvi y los primeros decenios del xviI.

56. Fernando Lázaro Carreter, op. cit., p. 293.

57. "La propagación de los hechos de lengua está sujeta a las mismas leyes que cualquier otra costumbre, la moda por ejemplo. En toda masa humana hay dos fuerzas que actúan sin cesar simultáneamente y en sentidos contrarios: de un lado el espíritu particularista, el 'espíritu de campanario'; y del otro, la fuerza de intercambio que crea las comunicaciones entre los hombres [... ] Si el espíritu de campanario hace a los hombres sedentarios, el intercambio los obliga a comunicarse entre sí [... ] En una palabra, es un principio unificador, que contraría la acción disolvente del espíritu de campanario [... ] Al intercambio se debe la extensión y la cohesión de una lengua. D e dos maneras opera: ya negativamente, previene el despedazamiento dialectal ahogando una innovación en el momento de surgir en un punto; ya positivamente, favorece la unidad aceptando y propagando esa innovación [... ] En un punto dado del territorio - entendiendo por tal una superficie mínima equiparable a un punto, una aldea por ejemplo- , es muy fácil distinguir qué es lo que depende de cada una de las fuerzas en presencia, el espíritu de campanario y el intercambio; un hecho no puede depender más que de una, con exclusión de la otra; todo carácter común con otro hablar depende del intercambio; todo carácter que no pertenezca más que al hablar del punto en cuestión se debe a la fuerza de campanario." Saussure, op. cit., pp. 327-330.

58. Amado Alonso, Estudios lingüísticos. Temas hispanoamericanos, M adrid, G redos (Biblioteca Románica H ispánica, II. Estudios y Ensayos, I2), 1967, p. II [ia. ed. en I953]. El mismo Alonso nos pone en guardia respecto a que cuando se pretende decir que el hablar peninsular trasladado a América fue la modalidad vulgar o plebeya, se comete un grave error histórico. Baste recordar a Balbuena en el epílogo de su Grandeza mexicana (I606), p. I7. 
Asumimos el término nivelación por considerar que explica de forma más completa el fenómeno de transformación que sufrió la pintura europea en América, hasta convertirse en "la pintura española americana". Por lo mismo, desechamos los términos "influencia", "eclecticismo" y "mestizaje" para explicar la forma pictórica americana utilizada durante la época de los virreinatos. El primer término porque supone una base preconstituida sobre la que actúa un elemento externo y nuevo que reconduce el futuro de esas formas, pero que permanece siempre distinguible y separable; el segundo presupone una selección de elementos unidos en una especie de rompecabezas en la que los variados componentes se pegan unos a otros pero no se asimilan y permanecen identificables. Y el mestizaje porque deja intactas las dos categorías raciales que la componen, que no sólo por ser raciales no funcionan en un producto cultural, sino porque, al igual que en los términos "influencia" y "eclecticismo", permanecen identificables y sin posibilidad de desaparecer en función de la unidad. La nivelación supone una base común en la que todos los elementos comunes espontáneamente se aglutinan y son asimilados formando un todo homogéneo, indivisible y solidario en sus partes, difícilmente analizable, creándose, para la pintura, como en el caso de la lengua, una verdadera koi né regional. 59

59. Fernando Lázaro Carreter en su Diccionario de términos filológicos, p. 96, define una coiné o koiné como: "Lengua común, de base ática, que adoptan los griegos desde fines del S. IV a. J.C. dando fin al periodo dialectal. Por extensión del significado anterior, cualquier lengua común que proceda de una reducción a unidad más o menos artificial, de una variedad idiomática", p. 96. También J. Siegel dice: "Una koiné inmigratoria se desarrolla en una comunidad inmigratoria amalgamada y a menudo es la lengua materna de la primera generación nacida en esa comunidad." Citado por Fontanella en op. cit., p. 48. Saussure indica que: "la diversidad absoluta plantea un problema puramente especulativo. Por el contrario, la diversidad en el parentesco nos pone en el terreno de la observación y puede ser reducida a unidad [... ] No hay que imaginar que el idioma trasplantado será el único en modificarse, mientras el idioma originario quedaría inmóvil; tampoco lo inverso se produce de manera absoluta; una innovación puede nacer de un lado, o del otro, o de ambos a la vez". Y agrega: "La diversidad geográfica es, pues, un aspecto secundario del fenómeno general. La unidad de los idiomas emparentados no se vuelve a hallar más que en el tiempo. Éste es un principio con el que los comparatistas deben compenetrarse si no quieren ser víctimas de engañosas ilusiones". Saussure, op. cit., pp. 314-316. D ebemos agregar, hablando de la nivelación, que la "analogía" es un caso de nivelación ya que consiste en la adopción de comportamientos y rasgos lingüísticos semejantes, los cuales nos pueden ser útiles en el estudio de la pintura, quizá para analizar la asunción y generalización de convenciones salidas de grabados o pinturas europeas. El calco (de esquema y de significación) y el préstamo (léxico por lo general) también son fenómenos 


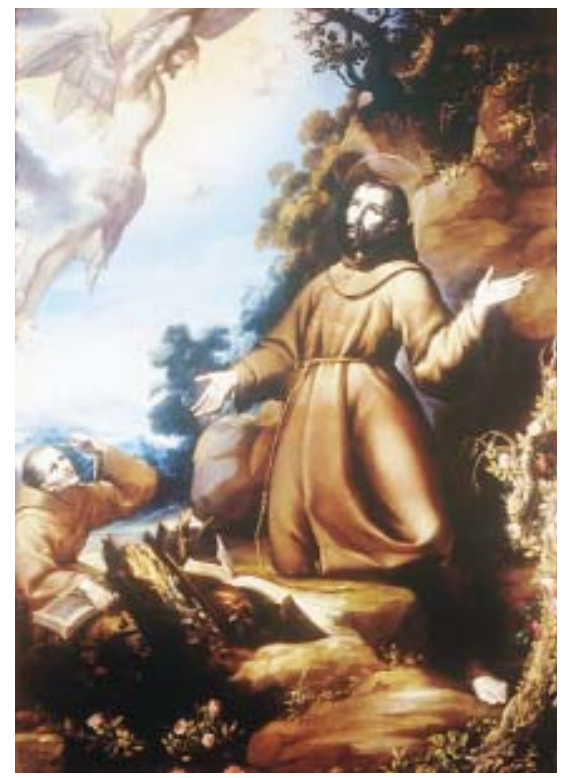

19. Sebastián López de Arteaga, La estigmatización de San Francisco, M useo de la Baślica de Guadalupe. Foto: Archivo Fotográfico IIE-UNAM.

Si consideramos que la creación del lenguaje pictórico novohispano y americano, en general, se constituyó por nivelación, podremos considerar los resultados como verdaderas variedades dialectale ${ }^{60}$ de la pintura española con

de nivelación [o la favorecen]. Lázaro Carreter, op. cit., p. 293. Esto traería a los indígenas a participar en la nivelación.

6o. "Los dialectos son modalidades adoptadas por una lengua en cierto territorio, dentro del cual está limitada por una serie de isoglosas, es decir, por una línea ideal que puede trazarse en un territorio, señalando el límite de un rasgo o fenómeno lingüístico [... ] Sin embargo, cuando se han querido dar los límites geográficos de un dialecto, se ha tropezado con el hecho de que son frecuentemente borrosos y graduales [... ] D e ahí que se haya manifestado la idea de que los dialectosforman un 'continuum' sin límites precisos que varían insensiblemente... " Fernando Lázaro Carreter, op. cit., pp. I40-I4I. I dea que se podría aplicar a las tranformaciones del lenguaje pictórico a través de toda América pero con el objeto de registrar las áreas dialectales dentro de un diasistema "dentro del cual las discrepancias entre los sistemas no serán más que variantes de una misma unidad pictórica". I dem. Saussure prefiere utilizar, para señal ar estas sutiles líneas fronterizas, el término "ondas de innovación". Saussure, op. cit., p. 323. La utilización de dialecto [entendiéndose como variedad de una lengua] no sólo se justifica porque habla de la relación entre los lenguajes comparados, sino también por cuestiones de comprensibilidad. No hay comprensión cuando hay lenguas diferentes, en cambio sí la hay entre dialectos. 


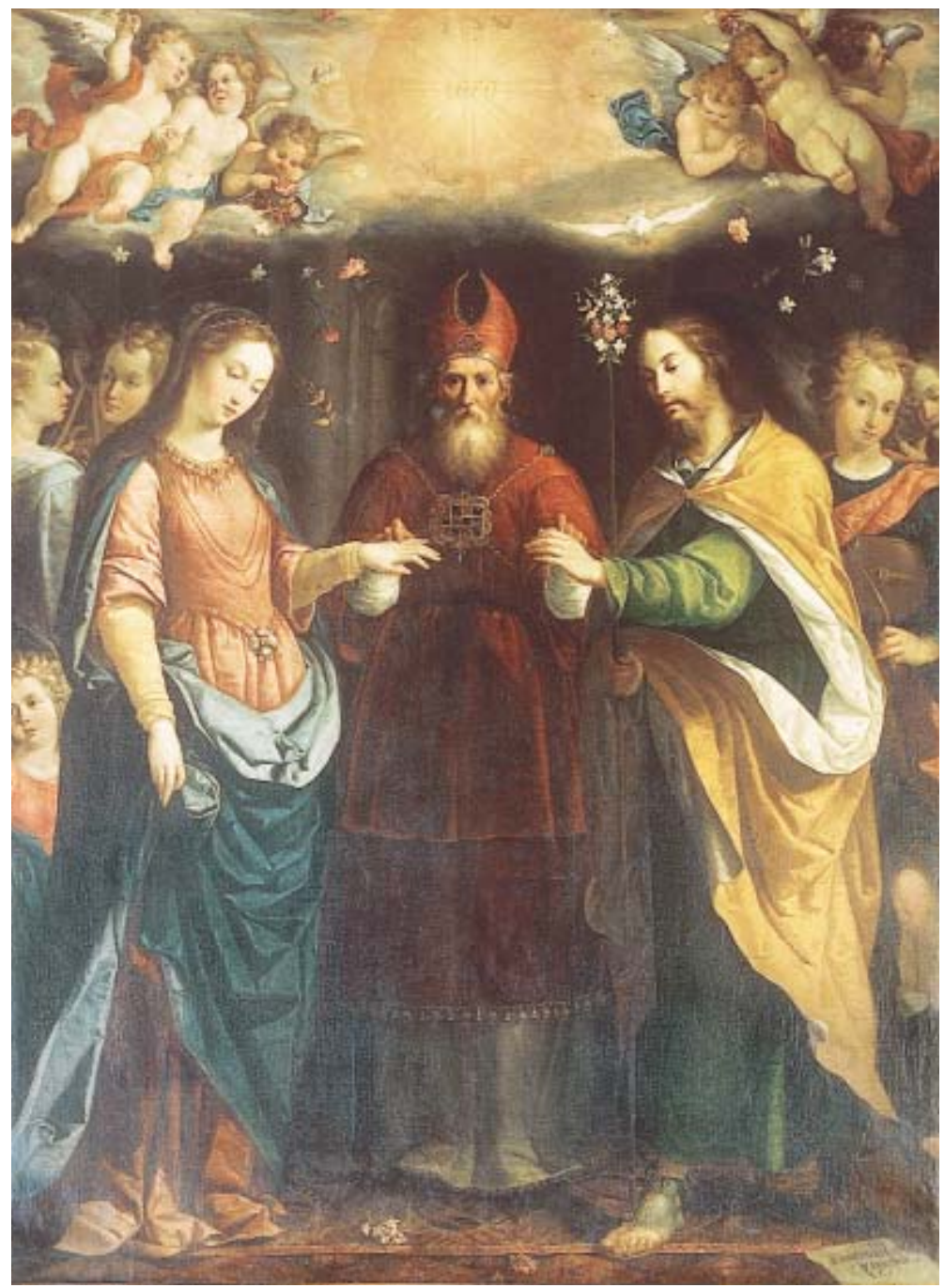

20. Sebastián López de Arteaga, Los desposorios de la Virgen, M useo N acional de Arte. Foto: Pedro Cuevas, Archivo Fotográfico IIE-unAm.

una implícita labor creativa y original que las hace diferentes de la pintura de origen. La formación de áreas pictóricas distintas en el continente americano se dará, al igual que en la lengua, en todos los puntos de dominio de este lenguaje pictórico originario cuando es abandonado a su evolución natural. Es- 
tas áreas no pueden ser previstas y determinarse de antemano su extensión, por lo que tenemos que limitarnos a registrarlas, como dice Saussure. ${ }^{6 \mathrm{I}}$

La conquista y la colonización de América se hizo con los pueblos de todas las regiones españolas. M ientras vivió la reina I sabel, hasta I504, eran sólo admitidos en la gran empresa los vasallos de la Corona de C astilla, con exclusión de los de Aragón; desde i504, todos los españoles podían llegar a las Indias y no sólo ellos. ${ }^{62}$ Los portugueses fueron también en buen número, y unos pocos de otros países europeos, ${ }^{63}$ y entre éstos, para el caso pictórico novohispano, tendríamos que nombrar el impacto importantísimo de los flamencos, casi paradigmáticos por las veces que su pintura es nombrada por los cronistas; y para el caso peruano, el de los italianos. Aunque debemos abrir un paréntesis, ya que no todos los elementos que se conjugaron para lograr una nivelación provinieron de "hablantes" (ipracticantes de la pintura?), sino también de grabados y de pinturas importadas (¿literatura?). Pero debo insistir, como quedó aclarado en una de las notas a pie de página, que el calco, el préstamo y la analogía se pueden dar a partir de grabados y pinturas, porque a través de ellos se aprenden y generalizan usos pictóricos y, por lo tanto, se pueden considerar como partícipes de los procesos de nivelación conjuntamente con la pintura hecha por los "ejecutantes" avecindados en la N ueva España. Por lo cual, para explicar el proceso de formación de la variedad americana tanto de la lengua como de la pintura, tenemos que admitir que su primer fermento característico es que se hizo a través de un trasplante de lenguas regional y socioculturalmente diferenciadas, en un juego de diversidades dentro de la unidad del idioma, creándose de principio una situación de heterogeneidad lingüística necesitada de al gún tipo de acercamiento entre las diferencias, y que su nivelación se llevó a cabo, en lo fundamental, sobre la base del lenguaje artístico y las reglas del arte ininterrumpidamente llevadas al Nuevo Mundo por los emigrados españoles. Es decir, aunque en desigual

6r. Saussure, op. cit., p. 319.

62. Si bien es verdad que los aragoneses, catalanes y valencianos acudieron en escaso número, ya que su emigración estaba dirigida hacia los dominios aragoneses y catalanes en el Mediterráneo, como Cerdeña, Sicilia, Nápoles, su influencia, aunque relativa, también se dejó sentir, y que esto valga también para la pintura, sobre todo el caso valenciano para los siglos siguientes. Sería pertinente recomendar el uso de estudios demográficos y de pasaje a las Indias para el estudio de la pintura en América.

63. Amado Alonso, op. cit., p. 39. 
proporción, cada contingente regional puso su propia nota en la constitución de los nuevos dialectos. ${ }^{64} \mathrm{Si}$ admitimos que lo característico de este trasplante es la variedad de regionalismos que lo constituyen, cabría preguntarse "si al Nuevo M undo se trasplantó un español básicamente nivelado 0 más bien un español con específicos rasgos regionales, sujetos a una ulterior y original nivelación americana". ${ }^{65} \mathrm{D}$ e igual manera, ante los documentos de pintores como Cristóbal de Quesada, registrado en Sevilla, pero natural de Carmona; ${ }^{66}$ Francisco I bía de Zumaya, ${ }^{67}$ vasco; Francisco de M orales, de Toledo, ${ }^{68}$ Arnaldo de Piamonte ${ }^{69}$ y más adelante con Pereyns, de Amberes, nos preguntamos si sus características regionales sufrieron una previa nivelación en España 0, pasando como "pintura española", vinieron a nivelarse a la N ueva España. Si la respuesta es que la nivelación se realizó en América, ésa no sólo sería una característica del trasplante americano, la multirregionalidad participativa, sino también una aportación, pues cabría afirmar que en España no había una norma general, sino que se constituyó en estas tierras.

Del mismo modo, debemos considerar que los materiales lingüísticos y pictóricos utilizados en la nivelación provenían en buena medida de la norma de los más cultos, pero que también se convivía con una diversidad de índole sociocultural. En la pintura no todos los pintores llegaban, como Pe reyns, con carácter de pintores de cámara de los virreyes. Si sabemos que en la emigración general predominó un elemento popular,70 debemos admitir, aunque para el caso de la pintura no esté bien documentado, que sucedía de forma similar dentro de este grupo artístico, aun si no conocemos los nombres de estos pintores populares. Tomando en cuenta que tanto frailes como otros muchos pintores que llegaron a las Indias por aquellos años no serían necesariamente artistas que cultivaran la "norma más culta", de igual manera sabemos que no todas las pinturas que se documentaban para ir a las Indias

64. José Antonio Frago García, H istoria del español de América. Textos y contextos, M adrid, Gredos (C ol. Biblioteca Románica H ispánica), I999, pp. 8-ı.

65. Ibid., p. I2.

66. Tovar de Teresa nos dice que G estoso y Pérez en su Diccionario de artífices sevillanos así lo registra. Guillermo Tovar de Teresa, Pintura y escultura en N ueva España (I557-I640), M éxico, Grupo Azabache, 1992, p. 52.

67. Toussaint, op. cit., p. 218.

68. Tovar de Teresa, op. cit., p. 67.

69. Ibid., p. 56.

70. Frago, op. cit., p. I2. 
DOI: http://dx.doi.org/10.22201/iie.18703062e.2002.80.2107

90

JUANA GUTIÉRREZ HACES

fueron Rubens o Tizianos, sino lotes de oscuros pintores o productos comercializables de talleres más o menos relevantes.

A continuación me permito glosar y transformar un extenso fragmento de la obra citada de Amado Alonso, que creo podemos aplicar al fenómeno pictórico novohispano y probablemente al americano en su totalidad, ya que por su claridad nos dará luces para entender a cabalidad cómo procedió el fenómeno de nivelación usado por los lingüistas, y que explica también la aparición de una pintura original americana de forma similar a la lengua española en América.

¿Q ué lenguaje llevaban consigo estos españoles al entrar en los barcos expedicionarios? Pues el practicado en la región respectiva. [Y lo mismo podemos decir del estilo de los pintores que llegaron desde los primeros años, ya que eran bastante variadas sus procedencias: Amberes, Sevilla, Carmona, el país Vasco, de no despreciable influjo, Valladolid, Toledo, etcétera.] Aquellos españoles, como todos los demás humanos, hacían funcionar sus hablas [y su pintura] entre los dos extremos que Ferdinand de Saussure llamó "espíritu de campanario" e "intercour$\mathrm{se}^{\prime \prime}$, un anglicismo que traducimos por intercambio, tendencia a lo general, comunicación de mayor radio de alcance que la aldea natal. Cada expedicionario, como todo hablante, [y después cada pintor] hacía oscilar su lenguaje entre el uso local y el uso general. El uso local lleva a la fragmentación indefinida [... ] El uso general lleva a las lenguas nacionales, y se va cumpliendo e imponiendo por nivelaciones y compromisos, cada vez más extensos y más profundos, orientados generalmente desde el hablar de la región directriz: [en el caso de la lengua] desde el reino de Toledo, cuyo hablar era tenido por todos los españoles como el mejor, identificado con el hablar cortesano, y sobre el cual habían formado y se guían formando entre todos los poetas y escritores españoles, castellanos o no, la lengua literaria, a su vez el más poderoso instrumento de nivelación general..$^{71}$

7I. Amado Alonso, op. cit., p. 4I. A pesar de que la norma "toledana" es aceptada, Ramón M enéndez Pidal, op. cit., acusa que para la segunda mitad del siglo xvı, ésta entra en crisis: "La revolución de fines del siglo xvi no fue, en efecto, sino la última y decisiva batalla librada por una norma dialectal castellano-vieja contra el prototipo lingüístico cortesano-toledano. Esa batalla fue, sin duda, ganada gracias al auge político-cultural de M adrid en la España filipina", p. гог. "Al mismo tiempo que el fonetismo dialectal castellano-viejo, con su avance al Sur del Guadarrama, amenazaba derrumbar la norma 'cortesano-toledana', que había venido rigiendo secularmente el español medieval, Andalucía contribuía a la crisis del español rebelándose también contra la primacía lingüística de Toledo. La Andalucía había al canzado a par- 
En pintura tendríamos que decidir cuál era la región pictórica directriz en la península española: si existía para la pintura al go equivalente a la norma "toledana" de la lengua española, o en su defecto cuál podía haber sido el resultado de la nivelación que se efectuaba en España al momento de la colonización de América. H asta dónde, al igual que para la lengua, Ilegó la influencia del elemento andaluz para la pintura. ${ }^{72}$ Asimismo, considerar si la pintura flamenca o italiana que pasó a América se encontraba nivelada con la española, y si esto no ocurría, cuál "norma" ejercía su influjo y cómo, ya que para el caso italiano no podemos considerar como iguales la nivelación hecha a partir de Florencia, Roma o Génova con la pintura española. ¿O si estas "normas" pasaban "puras" a América para ser niveladas aquí? Y ya que la nivelación se fue dando en el tiempo, decidir qué lugar ocupó Rubens en esta nivelación. ${ }^{73} Y$ todo esto de qué forma se unió a la nivelación técnica y lexical que sufría la pintura indígena. Y después el juzgar en qué momento se logró un dialecto, lo más estable posible, para considerar la eclosión de la "pintura novohispana".

La proporción en que entren en cada persona el espíritu de campanario y el deseo de generalidad determina en gran parte el sesgo que cada uno da a su hablar ly a su pintura] y, sumadas las personas y las generalizaciones, determinan el rumbo que la lengua [o la pintura] tome en su incesante evolución. Pues justamente en los años del descubrimiento, de la conquista y de la colonización, en España entera se acentuó y agrandó el sentido nacional de la lengua, la atención a un instrumento de comunicación de alcance general. ${ }^{74}$

H echo comunicativo que también se percibe en la pintura.

tir de los últimos años del siglo xv un extraordinario engrandecimiento, gracias a las dos mayores fuerzas propagadoras del idioma que entonces operaron, la reconquista y los descubrimientos geográficos", p. I04.

72. Se debería partir de un censo (hasta donde los documentos lo permiten, ya iniciado por Toussaint y seguido por Tovar y otros) para ver qué pintura regional se traía a América, donde, por ejemplo, al igual que de los andaluces, habría que considerar el peso de los vascos en la primera oleada de emigrantes.

73. Resulta interesante observar cómo a partir de Rubens muchos pintores novohispanos ajustan su estilo y, a pesar de palpar la filiación al rubenismo, pudieron avanzar de forma original e innovadora, como en el caso de Cristóbal de Villalpando.

74. Amado Alonso, op. cit., pp. 4I-42. 
Allá en su región nativa, cada futuro expedicionario, cumpliendo con su personal ecuación la ley de Saussure, tenía por lengua el dialecto o modalidad regional más la otra de alcance extrarregional (y más culta por lo general), común a todas las regiones [... ] La proporción en que entraban lo regional y lo nacional variaba con las regiones [... ] Atendamos ahora a hechos reales y a sus consecuencias necesarias: aquellos regionales se desgajan de sus regiones y se juntan y aglomeran para formar una nueva sociedad. Se juntan y aglomeran ya en los barcos expedicionarios, ya en los puertos de embarque [ya en los talleres pictóricos, de Andalucía, ya en los talleres novohispanos en las nuevas tierras] [... ] Como la lengua [y la pintura] son un instrumento social de comunicación y de acción interindividual, instintivamente elige el hablante, de entre los modos de que dispone, aquellos que sean los más adecuados para actuar sobre su oyente [0 espectador, patrono, fruidor o usuario].75 El destinatario es un real colaborador en nuestro modo de hablar [y en nuestro modo de pintar]. Salen, pues, los regionales de su región, deja el destinatario de ser su corregional, y automáticamente el hablante [o pintor] deja de usar en lo que puede los modos exclusivamente regionales y usa los más generales que ya sabe, y aprende otros que sirvan para los nuevos prójimos. En suma, si cambia permanentemente el tipo de destinatario, cambia también el tipo del hablar [y de comunicarse por cualquier medio, en este caso, la pintura]. $\mathrm{H}$ echo real y necesario es que, al juntarse en una nueva y concreta población americana, aragoneses, andaluces, castellanos, leoneses, extremeños y vascos, todos ellos y cada uno en su esfera personal acrecentaban en su hablar [y forma de pintar] la proporción de lo general y relegaban proporcionalmente lo regional hasta donde les fuera posible y tuvieran de ello conciencia. Ya se sabe: si se juntan y dejan en una isla desierta dos personas de lenguas extremadamente dispare jas, en el acto se inicia la gestación de una tercera. ${ }^{76}$

Amado Alonso concluye: “¿Cuál es la base lingüística del español de América?" Y contesta resueltamente: "L a verdadera base fue la nivelación realizada con todos los expedicionarios en sus oleadas sucesivas durante todo el siglo xvi. Ahora empieza lo americano".77 ¿C uál es la base de la pintura novohispana? Pues la nivelación de todos aquellos pintores europeos que llegaron a estas tierras durante los siglos de colonización con el agregado indígena, tan-

75. Las cursivas son mías.

76. Ibid., p. 44 .

77. Idem. 
to lexical como la particular forma en que asimilaron el lenguaje europeo y lo aplicaron.

El arranque 0 base de la modalidad americana no está fuera de ellos, de los americanos. Está en dos órdenes de leyes, ambos internos a los hablantes y a los artistas.

El primero de lingüística general: toda lengua viva [y podemos añadir, todo lenguaje pictórico vivo] y practicada evoluciona sin cesar como condición inseparable de su funcionamiento mismo; la evolución consiste en olvidar e innovar; lo uno y lo otro son en su origen actos individuales, y su grado y rapidez de ge neralización dependen de condiciones sociales.

Los lenguajes americanos, tanto el verbal como el pictórico, tenían que evolucionar, como también lo hizo el de España.

El segundo [orden de ley] es de carácter histórico y particular, y se inscribe el primero en el sentido de que el uno declara el evolucionar como necesario, y el otro se refiere al modo particular de la evolución. El modo particular de la evolución tiene a su vez dos fundamentos, el uno negativo y el otro positivo. El negativo se refiere a que una sociedad que se queda y continúa su historia en España, y otra que se forma al otro lado del mar, aunque sea con elementos de la primera, no podrán cumplir la evolución obligatoria de modo coincidente en todos sus términos; ni siquiera los españoles todos de la Península lo han podido hacer, como se ve por las regiones castellanizadas desde el siglo xi; y esto porque la tendencia a la generalidad y el espíritu localista se combinan en modo vario en las varias regiones, en los varios lugares y en los varios individuos; aquí lo verdaderamente admirable no es que América haya desarrollado una modalidad o modalidades diferentes de la peninsular o de las peninsulares, sino que en general la lengua [y la pintura] se hayan mantenido tan cercanas a ambos lados del mar en cuatro siglos y medio de historia. ${ }^{78}$

En el estudio de la pintura debemos considerar tan sólo los siglos de la Colonia. Concluye Alonso. "En suma, la sociedad hispano-americana se puso a funcionar de modo peculiar desde el día en que se constituyó, y ello determi- 
nó una peculiaridad paralela en el funcionamiento del idioma [y el lenguaje pictórico]."79 Interesante es notar que los españoles realizaban dentro de su lengua y quizá dentro de su pintura una nivelación interna y que al llegar a América realizaran otra.

Si atendemos al origen de la pintura que fue traída a N ueva España, procedente de toda la monarquía hispánica y aun aquella fuera de su territorio, nos daremos cuenta de que, al igual que la lengua, la pintura se encontraba en proceso de nivelación: distintas influencias preñaban esta pintura y, al igual que existía una pintura cortesana y "central", existían escuelas regionales que de continuo se nivelaban impulsadas por la necesidad y funcionalidad de su pintura. Al llegar los pintores europeos a la N ueva España realizarían de nuevo otra nivelación con los ya establecidos anteriormente. Casos como el de Simón Pereyns serían paradigmáticos: pintor nacido en Amberes, escuela particular dentro de la pintura flamenca, se dice que quizá fue alumno de M artín de Vos, que a su vez lo fue de Franz Floris. D e de Vos se sabe que había estado en Venecia, donde trabajó en el taller de Tintoretto. ${ }^{80} \mathrm{Pe}$ reyns pasó después por Portugal, donde multitud de pintores flamencos de diferentes regiones se nivelaban a sí mismos con otras influencias. Una vez llegado a España, se le considera un pintor romanizado, es decir, con influencia de la pintura romana, aunque aquí cabría hacer una explicación de lo que esto significa: ¿era a la manera de Rafael o de su discípulo Giulio Romano?, sólo por nombrar a dos pintores con estrecha relación entre ellos pero diferentes en resultados, y desde luego con influencia sobre Pereyns. Establecido en N ueva España y al servicio de la corte (viene en el séquito del virrey marqués de Falces), estará en contacto no sólo con pintores indígenas a su servicio, sino con Andrés de Concha, sólo por nombrar al más documentado en su relación, que era de origen sevillano, "formado en los talleres sevillanos, acaso como discípulo de Luis de Vargas". ${ }^{81}$

0 tro ejemplo de lo que es nivelación podría ser Sebastián López de Arteaga (I6IO-1650), aunque en este caso no es la nivelación que sufrió en Europa sino en América la que me interesa. López de Arteaga era sevillano, donde funda un taller. Abandonando Sevilla va a Cádiz, donde se hace evi-

79. Ibid., p. 58.

80. Nina Ayala Mallory, La pintura flamenca del siglo XVII, Madrid, Alianza Forma, 1995, pp. $20-25$.

8I. Tovar deTeresa, op. cit., pp. 83 y ss. 
dente la influencia de Zurbarán. ${ }^{82}$ Aunque ahora sabemos que más bien seguía los pasos de Pacheco, Juan de Roelas y Francisco H errera el Viejo y en momentos los del joven Velázquez. ${ }^{83}$ Alrededor del año de 1640 se embarca para América y al igual que Pereyns quizá forma parte de un séquito virreinal, en este caso del marqués de Villena. Claroscurista y muy atento a la forma de pintar de Zurbarán, cambia en la Nueva España su forma de hacer pintura, tanto que Xavier M oyssén dice:

Las obras conocidas de Sebastián de Arteaga presentan serias dificultades para su estudio. D e hecho son ocho los cuadros que con cierta seguridad se le atribuyen, básicamente por estar firmados; sin embargo, son tan distintos entre sí que de allí nace el primer obstáculo, pues no hay en ellos unidad estilística bien definida; aun las firmas que ostentan son enteramente distintas [... ] El colorido y la expresión de los personajes de las composiciones varían considerablemente. ${ }^{84}$

M ás adelante, al ir analizando los pocos cuadros conocidos de López de Arteaga y separar los de cuño claroscurista y zurbaranesco, M oyssén avanza sobre una de las obras más problemáticas: Los desposorios de la Virgen, y paso a paso revisa historiográficamente lo que se ha dicho de ella. Lo interesante es que todos los autores revisados demuestran su extrañeza sobre las diferencias que presenta este cuadro con el resto de sus obras, sobre todo con su Cristo en la cruz y con la Incredulidad de santo Tomás, así como con el San Francis co. Pero las observaciones del cuadro hechas por varios historiadores son las que resultan más interesantes para nuestro tema. M oyssén señala que: "A partir de Couto (I86I) se consideró como original de Sebastián de Arteaga el cuadro de L os desposorios de la Virgen, lo cual resultaba obvio puesto que está firmado"; M anuel G. Revilla (I893) lo tomó como tal, tras anotar que encontraba cierto parecido en algunas figuras con las pintadas por Baltasar de Echave $O$ rio y "ciertas incorrecciones de dibujo que serían de extrañar en un artista formado en la severa escuela de Ribera o de Zurbarán... " Francisco

82. Guillermo Tovar de Teresa, Repertorio de artistas en M éxico. Artes plásticas y decorativas, M éxico, Grupo Financiero Bancomer, 1996, p. 280.

83. Comunicación personal de Rogelio Ruiz Gomar.

84. Xavier M oyssén, "Sebastián de Arteaga (I6IO-I652)", en Anales del Instituto de Investigaciones Estéticas, vol. XV, núm. 59, unam-Instituto de Investigaciones Estéticas (M éxico, 1998), p. 25 . 
Diez Barroso (192I) repitió, con Revilla, que el cuadro "presenta bastante parecido con las obras de Echave, el Viejo". M anuel Romero de Terreros (I95I) al referirse a este cuadro dijo que tenía "una composición luminosa y brillante colorido de influencia rafael esca"; M anuel Toussaint agregó en 1934 (1965) que: "El tipo de la Virgen nos recuerda las madonas rubias del Perugino; la coloración cálida resuena con todos los tonos del arpa romanista". Es decir, agrega la pintura de Umbría, escuela a la que pertenecía Perugino, y añade muy decimonónicamente: "y sin embargo, hay diferencias que parecen impuestas por el medio..." porque alude a Roma. También Diego Angulo en I950 opina, y dice encontrar que en él, la pintura tenebrista aparecía "dulcificada" a pesar de que se hiciera evidente que era discípulo de Zurbarán, pero agrega que en este cuadro se halla el germen de lo que será el estilo de José Juárez. Justino Fernández, en 1959, la ve rafaelesca pero arcaizante; cuando se llega a M artín S. Soria (1959) de plano se dice que es una obra del taller de Arteaga pero con el estilo de José Juárez, tanto que pasó de inmediato a ser considerada como obra de Juárez. ${ }^{85} \mathrm{~N}$ elly Sigaut en su trabajo sobre José Juárez $(2002)^{86}$ no la atribuye ni menciona este parentesco notado por algunos historiadores, pero se muestra de acuerdo con Juan M iguel Serrera en que en una obra como la Incredulidad de santo Tomás la monumentalidad de las figuras y la forma de tratar los paños recuerdan a H errera el Viejo; los tipos físicos de los apóstoles, al joven Velázquez, y el Cristo, a modelos italianos, en particular genoveses, especialmente en el empleo de la luz que lo vincula a los caravaggescos, pero ante toda esta riada de influencias su juicio es duro, ya que dice: "La carrera de Arteaga [... ] desde que llegó a M éxico es tan importante como sorprendente. Arteaga, más que ecléctico, se muestra oportunista: su trabajo padece de la oscilación de un merolico visual, de al guien que está buscando satisfacer al cliente - 'que siempre tiene la razón'- sin la menor concesión hacia su propia personalidad." 87

Lo que todos estos juicios revelan es que el problema de Arteaga no es un problema y menos moral, sino que sólo es un pintor en proceso de nive-

85. Ibid., pp. 30-3I.

86. N elly Sigaut, “José Juárez: recursos y discursos del arte de pintar”, en JoséJ uárez. Recursos y discursos del arte de pintar, M éxico, M useo N acional de Arte/Banamex/Patronato del M useo Nacional de Arte/Universidad Nacional Autónoma de M éxico-Instituto de Investigaciones Estéticas/C onaculta-INBA, 2000.

87. Ibid., p. 95. Juicio que, aunque injusto, suponemos surgió de la pasión que desata este tema y que tenía su lugar en el excelente estudio que esta autora hace de José Juárez. 
lación, que no hay tal eclecticismo, sino que en él se ha producido la reducción de una serie de lenguajes pictóricos que se muestran de tal forma solidarios que se hace difícil el identificarlos y aislarlos, de ahí el vaivén de los historiadores del arte empeñados en encontrar paternidad y relaciones a la forma de pintar de Arteaga. También se hace notar que los cambios de estilo se dieron por "conveniencia" del autor para lograr la comunicación deseada con sus patronos y usuarios, como cualquier buen pintor de cualquier latitud hubiera hecho. Q ue sus transformaciones pictóricas ocurridas en la N ueva España no son incongruentes, sino que sólo su lenguaje pictórico, traído de la Península, se niveló con el de los novohispanos de aquel momento, y que la ley de Saussure se dio de manera eficaz, abandonando paulatinamente la forma de pintar que traía, optando por el lenguaje general utilizado por los pintores establecidos; de ahí la "dulcificación" que todos dicen se acusa en los Desposorios y su parecido con un maestro que lo antecedió: Echave 0 rio, y con un maestro más joven que es José Juárez, ya que todos, antes 0 después, bebían de esta nivelación. No es científico acusar a un pintor de oportunista, ni de merolico porque cambia su estilo: el resultado formal que acusa Sebastián López de Arteaga es el de un pintor que se nivela con su nueva realidad pictórica. Lo importante por el momento es señalar, con este caso extremo, lo que podría ser un caso típico de nivelación.

Todo lo anterior supone de parte del historiador del arte un riguroso estudio con descripciones y explicaciones precisas de lo que son los dos sistemas de representación. Entendiendo por esto el reducir a términos conocidos estos cambios y trabajar por comparación remitiéndonos siempre a otras formas evolucionadas.

Una de las formas como se podría estudiar el fenómeno de la nivelación en pintura es a través de la descripción del lenguaje pictórico mediante el análisis de sus distintos niveles: uno el diatópico o regional, otro el diastrático o referido al estrato social y cultural del emisor, ya que de ahí se pueden extraer los culteranismos o los vulgarismos, o incluso los arcaísmos en uso; y por último, su situación diacrónica y sincrónica.

Y como Saussure proponía, quizá

se debe abandonar el método prospectivo, al documento directo, y proceder en sentido inverso, remontando el curso del tiempo por retrospección. En esta segunda perspectiva el investigador se sitúa en una época dada para averiguar, no ya qué es lo que resulta de una forma, sino cuál es la forma más antigua que la 
haya podido producir. M ientras que la prospección resulta de una simple narración y se funda toda entera en la crítica de los documentos, la retrospección exige un método reconstructivo, que se apoya en la comparación. ${ }^{88}$

Logrado el estudio de la nivelación, podemos considerar la variante lingüística resultante como coiné (koiné), esto es, la creación de una lengua común donde se abandonan los regionalismos en función de una lengua general, atendible por toda una sociedad, ya que la koiné es cualquier lengua común que proceda de una reducción a unidad.

El término "koinización" es reciente (Siegel, 1985) y su aplicación al español americano fue hecha por Fontanella de Weinberg en 1987. Siegel considera que una koiné es el resultado estabilizado de la mezcla de subsistemas lingüísticos, tales como variantes regionales o literarias. En una revisión de trabajos en los que se han considerado diferentes casos de koiné, extrae los siguientes rasgos como característicos de todos o de al gunos de ellos:

- confluencia de distintas variedades de una misma lengua, aunque se base primordialmente en una variedad

- reducción y simplificación de rasgos

- uso como lingua franca regional

- surgimiento de hablantes nativos y estandarización ${ }^{89}$

Y todos estos rasgos son aplicables a la pintura americana. Respecto al surgimiento de pintores nativos y la estandarización de las convenciones pictóricas, podemos considerar que es la más significativa de estas características anotadas, puesto que nos indica que probablemente empezó a ser empleada por las primeras generaciones de pintores criollos. Para algunos lingüistas, a partir de la tercera generación en usar una koiné se habrá criollizado la lengua. $9^{\circ} \mathrm{H}$ abrá por lo tanto que identificar para la pintura el momento aproxi-

88. Saussure, op. cit., p. 338.

89. Fontanella, op. cit., p. 43.

90. D e Granda opina que el proceso de koinización se realizó hacia la tercera generación, en lo que M oreno de Alba coincide: "Es posible que, en la koiné americana, haya prevalecido, sobre el proceso de nivelación, el mecanismo de simplificación. La plasmación o cristalización de esa koiné (el español americano propiamente dicho) pudo demorar hasta la tercera generación de pobladores españoles, es decir, 'hasta los nietos de los conquistadores y primeros pobladores', algo así como 60 años". M oreno de Alba, op. cit., pp. I6-17. 
mado en que esta nivelación se efectuó y convirtió en koiné y dio origen a una variedad dialectal pictórica, que empezó, a partir de ese momento, a evolucionar de forma independiente y a dar frutos originales, aun cuando siempre quede una parte de rasgos comunes con el tronco lingüístico original. El término "criollización de la pintura", a pesar de ser discutible, podría ser utilizado, ya que la pintura no se había mestizado, como anotamos antes. Siendo un nuevo lenguaje pictórico distinguible, que podríamos considerar americano, y ya que la palabra criollo ha tomado carta de naturalización en los estudios históricos, alejándose de una connotación racial, para convertirse en sinónimo de americano, pudiera ser utilizado para calificar nuestra pintura. ${ }^{91} \mathrm{D}$ e ahí que sólo faltaría decidir si podemos considerar esta variedad dialectal pictórica domiciliada en la N ueva España como pintura española de América o dejarla, como sucede con la lengua, como pintura española en América.s

91. Juan Antonio Frago, op. cit., p. 30o, dice: “Por criollización es evidente que no entiendo aquí la formación de una nueva lengua surgida de la mezcla del español con otra, sino la alteración del español dialectalmente diferenciado llevado a América, base no ya fundamental, sino casi exclusiva, del fenómeno de regionalización lingüística que venimos considerando, a partir del cual surgió el 'español americano', nueva modalidad a su vez dotada de variedades socioculturales y geográficas menores, que no sólo se extenderían a todos los 'criollos', o nacidos en Indias, sino que acabaría siendo asumido por éstos como rasgo distintivo de su personalidad americana." 